\title{
U.S. POLITICAL CORRUPTION AND FIRM FINANCIAL POLICIES
}

by

\section{Jared D. Smith}

B.S. in Business Administration, University of Pittsburgh, 2009

\author{
Submitted to the Graduate Faculty of \\ the Joseph M. Katz Graduate School of Business \\ in partial fulfillment of the requirements for the degree of \\ Doctor of Philosophy
}

University of Pittsburgh

2014 
UNIVERSITY OF PITTSBURGH

JOSEPH M. KATZ GRADUATE SCHOOL OF BUSINESS

This dissertation was presented

by

Jared D. Smith

It was defended on

May 28, 2014

and approved by

Dr. David J. Denis

Roger S. Ahlbrandt, Sr. Chair and Professor of Finance

Katz Graduate School of Business

Dr. Leonce L. Bargeron

Assistant Professor of Finance

Katz Graduate School of Business

Dr. Kenneth M. Lehn

Samuel A. McCullough Professor of Finance

Katz Graduate School of Business

Dr. Shawn E. Thomas

Professor of Finance

Katz Graduate School of Business

Dr. Daniel M. Berkowitz

Professor of Economics

University of Pittsburgh

Dissertation Director: Dr. David J. Denis, Katz Graduate School of Business 
Copyright () by Jared D. Smith

2014 


\section{ABSTRACT \\ U.S. POLITICAL CORRUPTION AND FIRM FINANCIAL POLICIES \\ Jared D. Smith, Ph.D. \\ University of Pittsburgh, 2014}

Using a large panel of U.S. firms from 1980-2009, I examine the association between corruption on the part of political officials in a federal judicial district and the financial policies of public firms headquartered in that district. I find that corruption is negatively related to cash holdings, directly related to leverage, and that these relations are economically significant. These results are robust to firm fixed effects, an instrumental variable framework, the use of an alternative survey measure of corruption, and, further, are largest among firms who operate mainly around their headquarters. I also find that firm value tends to be lower when corruption is higher. Overall, the evidence suggests that firms reduce their capacity to pay bribes by managing liquidity downward and debt obligations upward when faced with a corrupt political environment. In other words, the local political environment plays a part in shaping financial policy. 


\section{TABLE OF CONTENTS}

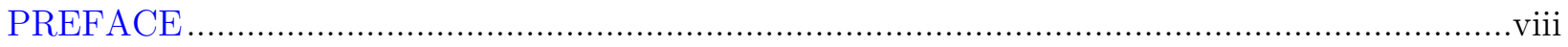

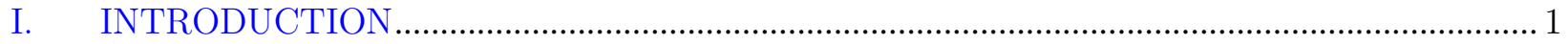

II. LITERATURE REVIEW AND HYPOTHESIS DEVELOPMENT ..................................8

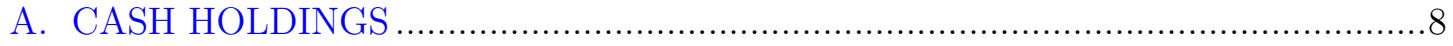

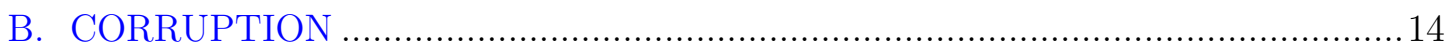

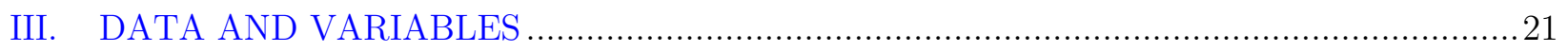

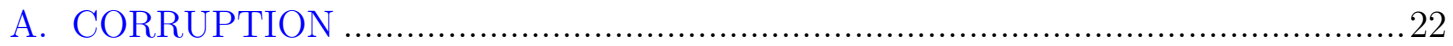

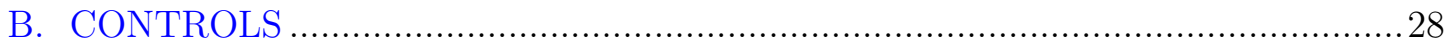

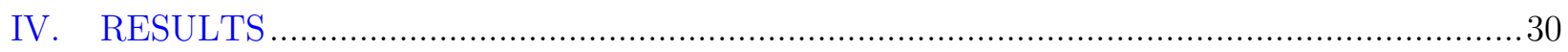

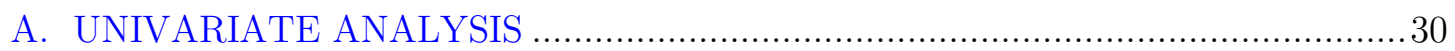

B. MULTIVARIATE ANALYSIS OF CASH HOLDINGS ..................................... 31

C. MULTIVARIATE ANALYSIS OF LEVERAGE .............................................. 34

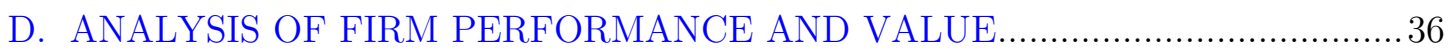

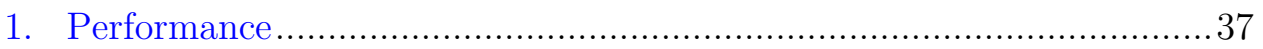

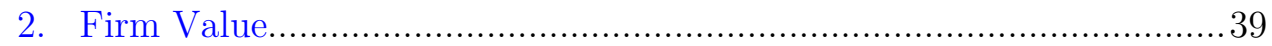

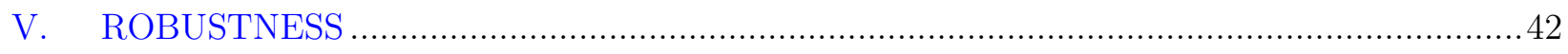

A. ALTERNATIVE SPECIFICATIONS …........................................................... 42

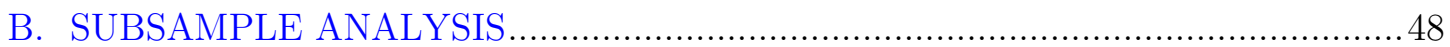

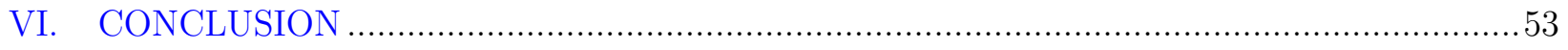

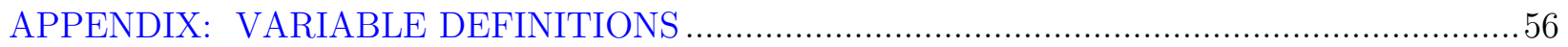

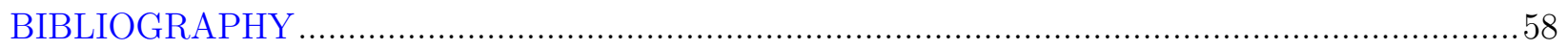




\section{LIST OF TABLES}

Table 1: Summary Statistics for Convictions per 100,000, by district...................................66

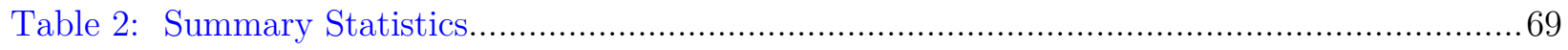

Table 3: Univariate Analysis by Corrupt and Non-corrupt Districts ..................................... 70

Table 4: Panel Regressions of Cash Holdings on Corruption.....................................................71

Table 5: Panel Regressions of Leverage on Corruption ........................................................ 73

Table 6: Univariate Comparison of Performance by Corruption .............................................. 74

Table 7: Panel Regressions of Market-to-book on Corruption .............................................. 76

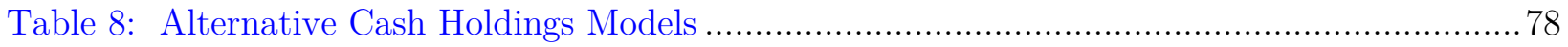

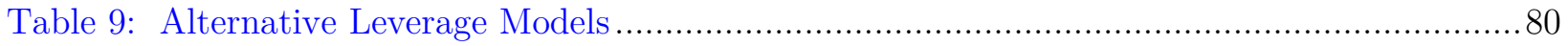

Table 10: Subsample Regressions of Cash Holdings and Leverage ............................................ 81 


\section{LIST OF FIGURES}

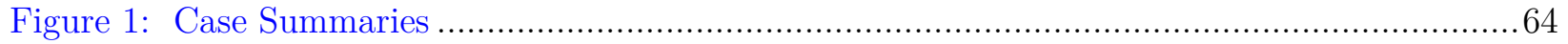

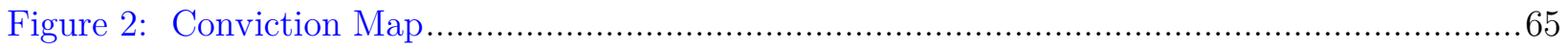




\section{PREFACE}

First, I would like to thank my loving (and lovely) wife Jenna, whose continuous support and grounding made this dissertation possible. Without her, I would likely find myself alone in a dark wood, the right road lost.

Second, I would like to thank my parents (Doug and Regina) and siblings (Ian, Elliot [who proofread many drafts of this paper], and Felicia), all of whom contributed to my successful completion of this program whether they realize it or not. They are all in one way or another responsible for the person I am today; blame them.

Third, I would like to thank all of the finance professors, and especially my dissertation committee, for their constant help throughout the dissertation process; whatever my thesis is today, they are in no small way responsible. I especially thank Professors Leonce Bargeron, Dave Denis, Ken Lehn, Marios Panayides, and Shawn Thomas. Their mentorship not only through the dissertation but through the entire doctoral program has been invaluable. Further, learning from them through direct apprenticeship on other research projects has been especially enlightening and rewarding, but also thoroughly enjoyable. I would like to thank them for that opportunity.

Fourth, my thanks to all the Ph.D. students that have helped keep me sane, pushed my papers along, and become great friends: Jesse Ellis, Michelle Frank, Ahmet Kurt, Patrick Martin, Anjana Rajamani, Tom Shohfi, Bryan Stikeleather, and Roger White.

Finally, a special thanks to Carrie Woods and everyone in the doctoral office. They define the word support. 


\section{INTRODUCTION}

The determinants of corporate financial policies have been the topic of a considerable amount of research among financial economists. Broadly speaking, this literature identifies two primary categories of factors that influence these policies: (i) firm and industry characteristics, such as asset tangibility and growth opportunities, and (ii) frictions in the market, such as adjustment costs. $^{1}$ In this study, I analyze whether a particular market friction, local political corruption, has an impact on corporate cash and leverage policies.

Corruption is defined as an elected or appointed official abusing the public trust for private gain or, more generally, the illicit rent-seeking actions of bureaucrats and politicians. Although the literature finds that the direct actions of politicians have real effects on firms (see, for example, Cohen, Coval, and Malloy (2011) who find private investment declines with public spending), the evidence is more limited on the issue of how corruption, or the threat of corruption, affects firms. A number of recent anecdotes demonstrate the pervasiveness of rent-seeking in the U.S. by corrupt officials, and suggest the possibility that the political environment could shape a firm's

\footnotetext{
${ }^{1}$ See, for example, Opler, Pinkowitz, Stulz, and Williamson (1999) for the seminal paper on cash holdings, and Graham and Leary (2011) for an excellent review of empirical capital structure research.
} 
financing decisions and balance sheet structure. ${ }^{2}$ Further, recent studies by Caprio, Faccio, and McConnell (2013) and Fan, Titman, and Twite (2012) find evidence consistent with the view that cross-country differences in financial policies are associated with cross-country differences in (the perception of) corruption. Nonetheless, it is difficult to conclusively determine whether these effects reflect a causal link between corruption and financial policies or whether they are due to omitted country factors.

In this paper, I develop and test the hypothesis that U.S. firms design financial policies to mitigate the effects of local corruption, that is, shield expropriable assets. This shielding hypothesis yields several empirical predictions. First, firms facing a more corrupt political environment will attempt to mitigate the risk of public officials extorting them by limiting their contractible surplus. Firms can limit their contractible surplus by reducing their cash balances and by using debt to reduce free cash flow and increase the likelihood that rent extraction could lead to insolvency. Politicians want to stay in power, so they seek rents without firm bankruptcies or large reductions in investor returns to reduce the likelihood of getting caught or voted out of office. Second, rentseeking imposes a deadweight loss on firms, so firm value is lower in more corrupt areas. Alternatively, because these data likely encompass political connections, firms could have a reduced need for financial flexibility through valuable political connections. This implies that firm value is greater in more corrupt areas.

\footnotetext{
${ }^{2}$ For example, former Illinois governor Rod Blagojevich was tried (for the second time) in 2011 on 20 counts of political corruption, most famously for his attempts to sell the Illinois Senate seat, but also for soliciting bribes and extorting Chicago-area firms. This is only one among a recent string of scandals that the media have highlighted. See also: "Crime and Politics: The Chicago way." The Economist February 25 page 40 .
} 
My main proxy for local political corruption is the number of public corruption convictions in each federal district court district in the U.S. scaled by district court population for each year. The conviction data are maintained by the Public Integrity Section (PIN) of the U.S. Department of Justice (DOJ). The PIN's principal aim is to investigate and prosecute abuses of the public trust including, but not limited to, extortion, bribery, and criminal conflicts of interest. I match corruption data to firms based on headquarters location.

In univariate and multivariate tests, corruption is negatively and significantly related to cash holdings. The magnitude of the relation is such that a firm with headquarters in highly corrupt Northern Illinois holds a cash ratio approximately 0.71 percentage points lower than a firm with headquarters in the low corruption district of Central Illinois, all else equal. Univariate and multivariate tests also show that corruption is positively and significantly related to leverage. Firms in Northern and Central Illinois have a 1.1 percentage point difference in short- and long-term debt as a percentage of assets, all else equal. These relations persist after controlling for many firm and industry characteristics, leading, lagging, and alternative ways of defining and scaling the conviction data. These magnitudes are similar to the results in international work. ${ }^{3}$

The rent-seeking hypothesis implies differences in the effect of corruption in the cross-section of firms. Politicians have more bargaining power with firms that operate solely in one area relative to firms that operate in many areas because these firms are fully dependent on their local dis-

\footnotetext{
${ }^{3}$ Caprio et al. (2013) find that the cash ratio is approximately $15 \%$ lower when corruption increases one standard deviation. Fan et al. (2012) find that leverage is about $13 \%$ higher with a similar increase in corruption.
} 
trict. The evidence is consistent with this intuition: the magnitude of the relations between corruption and cash and leverage are larger for a firm operating in a fewer number of states or with a larger percentage of its operations around its headquarters. For instance, a firm operating in a single, corrupt area will have a cash ratio 3.4 percentage points lower than a firm in a single, noncorrupt area. This is a $20.24 \%$ difference from the mean cash ratio. However, this difference is one quarter of that size, only $5.45 \%$ of the mean cash ratio, for a firm that operates in 25 states.

Further, my findings are robust to a number of additional tests that control for the possibility that an omitted variable (or variables) impact both corruption and firm financial policies simultaneously. First, the results are robust to using an alternative survey measure of corruption at the state level (and only available cross-sectionally) designed to grade states on the likelihood of conviction, which complements the use of actual convictions and sidesteps the criticism that the most corrupt districts could have the lowest number of convictions. Second, corruption is still associated with cash and leverage after controlling for time-invariant omitted effects by defining variables as changes or including firm fixed effects. Third, I use the concentration of state population around the state capital city as an instrument for state corruption. I find that instrumented corruption is positively and significantly related to leverage and the coefficient implies a large effect: a one standard deviation change in corruption implies a $10.77 \%(14.27 \%)$ change from mean (median) leverage. On the whole, I interpret the evidence as consistent with a causal link between corruption and firm financial policy. 
I also examine how firm value relates to corruption. Firm value is lower for firms facing a more corrupt political environment around their headquarters. Firms operating in Northern Illinois have a mean (median) market-to-book value $1.70 \%(2.90 \%)$ lower than a firm in Central Illinois, all else equal - a reduction of $\$ 4.32$ million in market capitalization for the median sample firm.

Overall, these results are consistent with firms attempting to shield their resources from outside attempts to consume them and that the decrease in financial flexibility lowers firm value. Firms reduce their liquidity to decrease their capacity to pay public officials, and they make the reduction more credible by increasing leverage as a way to commit future cash flow in the form of debt service. More leverage also increases the probability, and therefore expected cost, of bankruptcy, which could insulate firms from expropriation. The intuition for the interpretation is rooted in Stulz (2005), who suggests that firms will take action to limit state expropriation. Broadly, my results suggest that financial policy responds to market frictions, but also that firms can use financial policy to reduce the effects of some frictions.

This paper contributes to several streams of literature. First, it adds to the literature on the determinants of corporate liquidity (see, for example, Kim et al. (1998) and Opler et al. (1999)) as a cost of holding cash. ${ }^{4}$ Second, it extends the literature on how firms choose the portions of debt and equity in their capital structure, specifically on the strategic use of debt. More specifically,

\footnotetext{
${ }^{4}$ The cash holdings literature has been growing. A partial list of recent work includes: Foley, Hartzell, Titman, and Twite (2007), Harford, Mansi, and Maxwell (2008), Duchin (2010), Lins, Servaes, and Tufano (2010), Hoberg, Phillips, and Prabhala (2014), and the other research cited later in the paper.
} 
my study best fits with a growing literature on how the contracting environment affects corporate financial policies. For instance, Klasa, Maxwell, and Molina (2009) find that firms in more heavily unionized industries have significantly lower cash reserves, and Matsa (2010) finds that these firms use more debt capital. Both studies suggest firms are reducing their ability to pay abovemarket wages to unions. It is likely that this bargaining dynamic implicitly operates between firms and officials, as officials try to extract the maximum bribe without large reductions in investor returns.

This paper also contributes to the broad literature on corruption in two ways. First, corruption, while well-trodden in the traditional economics literature (beginning with Rose-Ackerman (1975)), has largely gone unstudied in the finance literature. Therefore, this paper adds to the few notable exceptions that study corruption as it affects the firm and market outcomes, rather than traditional macroeconomic or public choice variables. For example, Butler, Fauver, and Mortal (2009) find that corruption had a real impact on the municipal bond market: credit risk was greater and politicians awarded underwriting contracts based on political favoritism (see also Caprio et al. (2013) and Fan et al. (2012)). Second, limited survey data availability for U.S. corruption has led to most studies being focused internationally because of the well-known survey data for cross-country analysis. Therefore, focusing on corruption in the U.S. is a further contribution of this paper to the corruption literature because a within-U.S. study has several merits. First, as Fisman and Gatti (2002) note, within-country studies control for institutional (e.g., the tax environment and investor protection) and cultural (e.g., attitudes toward corruption) differences at the national level. Second, I focus on a nation that typically rates as having little corrup- 
tion in a world ranking (see, for example, International Country Risk Guide (ICRG)) that we might suspect does not experience corruption that affects firm operation because of the U.S.'s stronger rule of law and more well-defined property rights. One element of my paper is to show that despite a relatively clean reputation, corruption does exist at varying degrees throughout the U.S., and this variation can be used to study how local political corruption affects the firm. Along these lines, my paper is similar in spirit to Amore and Bennedsen (2013), who study the value of political connections in low corruption Denmark.

The paper proceeds as follows. In Section II, I review the literature on corruption and discuss my hypotheses. In Section III, I discuss sample construction, highlight the variables used in the study, and document the methodology. Section IV details the results. Section V discusses and reports the results of robustness tests. Finally, Section VI provides a brief conclusion. 


\section{LITERATURE REVIEW AND HYPOTHESIS DEVELOPMENT}

\section{A. CASH HOLDINGS}

An important assumption underlying my research question is that firms have an optimal cash balance, i.e., cash is not negative debt. In a perfect world, there are no costs to holding cash, no costs to raising debt or equity, and ultimately cash holdings (as well as financial policy in general)

do not matter. However, in the presence of market frictions, e.g., financing costs, cash holdings matter. Research on cash holdings commonly ascribes a number of different motivations to firms for holding cash: the precautionary, transaction, agency, tax, and predation motives.

The precautionary motive, often attributed to Keynes (1936), essentially posits that firms hold cash because of uncertainty in cash flows (i.e., the state of the world), the need to invest in those future states, and the cost of raising cash when it is needed (i.e., financing frictions). This notion suggests that firms with more valuable investment opportunities, more uncertain cash flows, or more costly access to external capital should maintain higher cash balances. The empirical literature on cash holdings strongly supports the precautionary motive. Along with Kim et al. (1998), Opler et al. (1999) is among the first studies to perform a large regression analysis to determine how firm characteristics relate to cash holdings. They find that firms with higher market-to-book 
and $R \& D$ expense, proxies for investment opportunities, or more variability in cash flows tend to hold more cash. They also find that firms that likely have low financing frictions tend to hold less cash. Almeida et al. (2004) attempt to directly link the importance of financial constraints with firms' demand for liquidity. They measure firms' propensity to save cash out of cash flow, termed the cash flow sensitivity of cash. They find that financially constrained firms have higher cash flow sensitivities of cash than unconstrained firms, suggesting that financial frictions do matter for managing precautionary cash holdings. Lins et al. (2010) survey chief financial officers (CFOs) from both public and private companies in 29 countries regarding their risk management policies (when they use cash and when they draw on lines of credit). The survey evidence supports the precautionary motive, as the CFOs indicate that they hold cash principally to guard against future cash flow shocks. Finally, Bates et al. (2009) examine why cash holdings have been rising to for several decades. They find that the increase in cash holdings is largely consistent with changes in firm characteristics that affect the precautionary motive; firms are more R\&D intensive, have riskier cash flows, and fewer inventories than years previous, all of which increase the amount of precautionary cash firms hold.

The transaction motive for holding cash, also often attributed to Keynes (1936), is the idea that firms have an optimal cash demand when there is a cost of turning non-cash assets into cash when a firm runs short of cash. This is similar to the precautionary motive, but rather than protect against adverse shocks, a firm wants to maintain an optimal cash inventory for normal operations. For an optimal cash balance to exist (and firms do not simply hold more than enough cash) there must be a cost to holding too much cash. This cost, which Opler et al. (1999) simply refer 
to as the liquidity premium, is the foregone revenue that comes from holding too much cash, a non-interest-earning asset. Early theoretical work, e.g., Baumol (1952) and Miller and Orr (1966), used inventory management models to show that optimal cash management follows the traditional "saw-tooth" diagram, in which the firm makes $L$ transfers of $M$ dollars from interest-bearing assets to cash every period. That is, at time 0 the firm transfers $M$ dollars to cash, and then runs this down (linearly in the model) to 0 until time $L$ when it again transfers $M$ dollars. This way, the firm maximizes interest income and minimizes the costs of running short of cash. One of the central empirical predictions is that economies of scale lead large firms to hold less cash, which is born out in existing studies (see Opler et al. (1999), for example). Additionally, the motive indicates that firms that need more cash in a period-e.g., for investment, or firms for which raising cash is more costly, e.g., those that cannot sell assets quickly - will hold more cash.

The agency motive for cash holdings is the notion that managers will hold vast sums of cash to pursue projects that may or may not be value-increasing. By using cash reserves, managers avoid the lender scrutiny that comes with accessing the capital markets. Jensen (1986) posited that too much cash under management led to value-destroying mergers and that restricting management's access to cash would increase firm value. Harford et al. (2008) use the anti-takeover provision count to proxy for managerial entrenchment and test the idea that poorly governed firms prefer cash holdings to external financing. They find that firms with poor governance generally have less cash, but they suggest this is because of managers spending cash quickly on acquisitions and other investment. Yun (2009), however, finds that poorly governed firms prefer unmonitored cash holdings to bank-monitored lines of credit, allowing them to avoid market disci- 
pline. Gao et al. (2013) is one of the first studies to examine the differences between public and private firm cash holdings. They find that, despite controlling for common factors that affect cash, private firms hold less cash than public firms. They argue that this must be because of the greater agency costs in public firms, as private firms face arguably greater financing constraints. Further, they argue that agency differences cause changes not only in the target but in the dissipation of excess cash, which they believe led to mixed findings. Dittmar and Mahrt-Smith (2007) use the methodology from Faulkender and Wang (2006) to explore how anti-takeover provisions affect the value of cash holdings. They use a regression of the change in firm value on changes in cash holdings interacted with the count of anti-takeover provisions and find that the value of cash is lower for firms with many anti-takeover provisions. They argue that the market values the cash holdings of poorly governed firms less, because managers are likely to spend it in value decreasing ways.

The tax motive for cash holdings suggests that, because the U.S. government taxes foreign income when a firm repatriates it, firms have strong incentives to hold this income as cash. This motive indicates that multinational firms, especially those with operations in many countries, would be disproportionately affected. Foley et al. (2007) use Compustat data and Bureau of Economic Analysis data on foreign cash holdings and find that firms facing higher repatriation costs hold more cash. Further, affiliates facing higher tax costs hold more cash than similar affiliates of the same firm that face lower tax costs of repatriation. 
The predation motive for cash holdings suggests that firms with investment opportunities that overlap with those of rivals should hold more cash, as the cost of underinvestment is potentially much greater for these firms if rivals invest in those projects. Haushalter et al. (2007) test the theory using industry concentration - specifically, the Herfindahl-Hirschman Index (HHI) - as a proxy for the likelihood of predation by rivals, because previous work (e.g., Kovenock and Phillips (1997)) suggested that investment was more likely to overlap in oligopolistic industries. They find that firms in more concentrated industries have greater cash holdings. Further, this effect is greater in industries with more growth opportunities. Hoberg et al. (2014) use Securities and Exchange Commission (SEC) 10-k filings to create a new measure, product market fluidity, to capture how rivals' actions change how their product market space overlaps with the firm's. This is similar to predation, yet it is a distinct construct, as it measures product market threats and instability that arise from rival actions. The authors find that firms with greatest fluidity, i.e., the most competitive threats, tend to hold more cash. The intuition links the predation and precautionary motives in that uncertainty increases the demand for cash holdings, but this is uncertainty that arises directly from rival firm actions.

Over the past several decades, firm cash levels have been rising to record levels (Gao et al. (2013) report that public firms have, "on average, $20.45 \%$ of their assets in cash or near-cash instruments.") In parallel with this growth in cash holdings, the academic literature on cash has been accelerating. This growth in the literature has largely been within the existing motives for holding cash, which researchers argue arise largely because of financing frictions, i.e., a wedge between the cost of internal and external financing. 
Despite this growth, however, researchers still have much to learn. The R-squared in crosssectional models of cash holdings is approximately $40 \%$, that is, $60 \%$ of the variation in cash holdings is still unexplained. In this paper, I depart from the more common analysis of motivations relating to financing frictions, and develop and test an additional market friction: political corruption, or extreme political uncertainty. Although I describe it fully next (Section II.B), intuitively, the idea is that public officials are rational agents seeking to maximize their own welfare. Oftentimes, this maximization comes in the form of extortion or the sale of political favors. However, officials balance requested bribes with both the probability of being caught, which I assume is higher for larger bribes, and the probability of being unelected, which is also likely to be higher for larger bribes because firms fail and investor returns fall. Thus, officials are likely to scale bribes to their perceived ability of the firm capacity to pay a bribe, in turn creating an incentive for firms to create a reduced capacity to pay. This is the crux of the "shielding assets from expropriation" hypothesis. This friction incentivizes firms to get rid of cash, in marked contrast to the financing friction which creates many motivations for firms to hold cash. This is one way in which my paper differs from previous papers on cash holdings: I hypothesize and test the presence of an entirely new friction, rather than investigating the existing motivations. 


\section{B. CORRUPTION}

Can public officials expropriate U.S. firms?

I use expropriation more broadly than the extreme negative connotation that it usually carries.

Stulz (2005, p. 1611) offers the following explanation: "By state expropriation, state rulers can decrease the returns of all firms, but they can also discriminate across firms so that they decrease the returns of some firms and improve the returns of others. States can tax cash flows, confiscate assets, forbid particular activities, or require bribes to enrich themselves. Therefore, the term 'expropriation' covers a wide range of activities." Throughout the paper, I use extortion and corruption to describe officials using the activities described above to enrich themselves at the expense of some or all firms.

Public officials likely are capable of extracting wealth from firms using "legal" means such as taxes and regulation. McChesney (1987) develops a model in which public officials use threats of regulation and narrow taxes in order to solicit bribes and extort firms. ${ }^{5}$ Figure 1, however, shows some of the case summaries the DOJ PIN submits in its annual reports to Congress. The three examples chosen represent different districts and time periods. Each shows a public official using his position to extort wealth from local businesses. Though not all cases handled by PIN are such clear cases of "shake-downs," Figure 1 does demonstrate that cases of severe abuse of office do oc-

\footnotetext{
${ }^{5}$ An example of a narrow tax is the "Windfall Profits Tax" that targeted the oil industry in 2007. Although in general this tax can be levied on any firm for any profit the government determines is "excessive," there was, amid record oil prices, a demand by many politicians to target gasoline producing firms because of perceived profits. Taxes and regulations aimed at specific industries are a potential avenue for politicians to gain concessions from firms, whether monetary or political.
} 
cur and are common. One of the more famous cases handled by PIN was the case of lobbyist Jack Abramoff in which an extensive investigation led to the conviction of Abramoff and 21 others including White House officials, a U.S. Representative, and Congressional aides on charges of corruption. The widespread scheme of bribery and defrauding the government shows that in many instances public officials rely on some sort of quid pro quo relationship in order to facilitate the transfer of firm resources. A promised quid pro quo is common in the case descriptions. Thus, there are also matters in which officials attempt to extract wealth illegally through outright blackmail and theft. Further, the convictions data appear to capture at least a portion of this activity, and my study relies on these data being a reasonable measure of this underlying corruption. ${ }^{6}$

Although corrupt officials in the U.S. may rely more on "legal" means of expropriation (e.g., threat of taxes and regulations, promised benefits), there does not appear to be anything unique about the way in which businesses pay bribes in the U.S. I am unable to observe all payments made to officials, even for those officials who are convicted, because only a subset of case descriptions is available. However, in those descriptions available bags of cash, foreign safe deposit boxes, and bars of gold are not uncommon.

Possible effects of corruption

Although far less developed than the literature on international corruption, there is some recent and on-going work on corruption in the U.S. Fisman and Gatti (2002) find that corruption is

\footnotetext{
${ }^{6}$ I discuss the validity of this reliance when I discuss the data (Section III.A).
} 
associated with larger federal transfers to states. Glaeser and Saks (2006) find that the number of corruption convictions is negatively correlated with economic development and investment measures in U.S. states, consistent with previous international findings. Butler et al. (2009) find that states with more corruption had riskier (more expensive) municipal bonds and that underwriting fees were much larger when politicians operated 'pay-to-play' schemes (i.e., corruption affected financial market outcomes). Current work on corruption within the U.S. examines how firms can mitigate the relation between corruption and firm value (Brown, Smith, White, and Zutter (2013)) and how firms dedicate resources to lobbying (Garner, Kim, and Yore (2012)).

In past international studies, corruption has been shown to be associated with slow economic growth and development by: distorting incentives, hindering market activity, and reducing private investment (Shliefer and Vishny $(1993,1994)$ and Mauro (1995)); reducing foreign direct investment (Wei (2000)); and transferring resources from the innovative, entrepreneurial elements of the economy (Murphy, Shliefer, and Vishny (1993)). ${ }^{7}$ Durnev and Fauver (2010) explore the ideas from Stulz (2005) and show both theoretically and empirically that when firms are at greater risk for having their assets extracted by public officials (which they simply call predatory government policies, or predation by states), firms tend to practice more opaque disclosure policies. They find that expropriation risk (defined by International Country Risk Guide data) drops average firm value by $3 \%$, and the resulting inferior governance and transparency drops average firm value by

\footnotetext{
${ }^{7}$ Jain (2001) and Aidt (2003) provide surveys of the corruption literature that demonstrate its breadth and depth and provide citations to many more studies than those I list here.
} 
$9 \%$. These figures provide some indication of the costs of corruption. These costs are inherently difficult to measure given the illicit nature of corruption.

Stulz (2005) and Durnev and Fauver (2010) both posit that transparent firms are faced with a greater threat of extraction or predation because government officials know more about these firms, effectively making expropriation easier. Therefore, firms have an incentive to be less transparent in these environments, leading to a decrease in the quality of reporting and disclosure. However, in countries with standardized and regulated reporting and disclosure, such as the U.S., it is possible that firms would need to take other actions to mitigate this expropriation risk.

What can firms do to mitigate expropriation risk?

Given that corruption does occur and that it can carry large costs, how can firms minimize these costs? Altering financial policies appears to be one channel through which to deter pursuit of firm assets.

Klasa et al. (2009) provide evidence that firms manage cash balances downward in more unionized industries to gain bargaining advantages over unions. In other words, these firms limit the cash that a party outside the firm can extract by appearing to have a diminished capacity to pay. In addition to managing liquidity, firms could use more debt financing to pre-commit cash flow (limit cash accumulation), increase profit variability, and increase the risk of bankruptcy. Matsa (2010) finds that firms strategically use debt in bargaining with labor unions likely to accomplish this aim. The findings in Matsa (2010) and Klasa et al. (2009) stem from early works in the in- 
dustrial organization literature by Bronars and Deere (1991) and Perotti and Spier (1993) who argue that debt could be used to intentionally increase the probability of bankruptcy and thus limit concessions made in a bargaining game. The notion of sheltering assets from the demands of labor unions fits naturally within the corruption literature; in a study on corruption in Uganda, Svensson (2003 p. 219) notes that "the more a firm can pay... the more it must pay."

Caprio et al. (2013) unify the ideas on liquidity management and corruption in an international setting. They build on Myers and Rajan (1998), who postulate that liquid assets are easier to extract and convert to private consumption (what Myers and Rajan call the transformation risk for "hard" assets), and Stulz (2005), who asserts that firms will structure assets to reduce the risk of expropriation. In the analysis, they examine a sample of firms in 109 countries and find that in countries ranked as more corrupt (by the ICRG survey) firms hold less cash on their balance sheets, pay more in dividends, and have more investment through capital expenditures and inventory.

Together, these papers suggest a foundation that: public officials are capable of expropriating wealth from firms, this expropriation is costly, and firms can alter financial policies to mitigate expropriation. This leads to a general hypothesis that U.S. firms will shield their assets from corrupt officials. The empirical predictions are as follows. First, cash is decreasing and leverage is increasing in the underlying amount of corruption a firm faces in its local political environment; this pre-commits liquid resources to creditors and increases the cost of expropriation to politicians because of the risk of bankruptcy. Second, these changes to firm financial policy result in lower 
firm value. It is plausible that there are many other changes to a firm's financial policies and balance sheet — working capital, inventories, etc. - but I leave this to future work.

These predictions and the subsequent analyses have important underlying assumptions. First, headquarters choice is pre-determined. That is, I assume the majority of firms evolve in certain areas for any number of reasons (e.g., in the founder's home city or because of an innovative environment such as Silicon Valley) and that they do not begin in such a fashion that they can simply locate wherever is optimal, weighing all factors (start-ups may not be aware of the local political environment). I do not attempt to address this in the paper. Second, there may well be corresponding benefits to operating in any area (including a district that my analysis would classify as corrupt) such as CEO preferences or reduced shipping costs. Three, moving a headquarters has a cost. As long as firms face some barriers to moving, they could be forced to adapt to the local political environment and these are the associations I hope to capture.

Relatedly, changing financial policies must be less costly than moving headquarters or paying corrupt public officials. If altering financial policies represents the highest cost undertaking then firms will instead pay the public officials or move and operate otherwise as normal, meaning I should find no significant results in the proceeding analysis. ${ }^{8}$ This is true of paying bribes because a firm would only carry an above-optimal amount of cash just before the bribe is paid, after which

\footnotetext{
8 This reasoning suggests that an analysis of firms that change headquarters location would provide an interesting test of the corruption hypothesis. Although headquarter changes cannot be identified through Compustat because it backfills these data, I have used the address line from SEC filings to create a sample of firms that change headquarters. However, the majority of relocations appear related to merger and acquisition activity, making it very difficult to draw conclusions about how a new corruption environment might be affecting the firm.
} 
the firm would return to its optimal cash balance. However, if altering financial policies represents the least cost action for the average firm, then to the extent that I can put a cost on changing these policies, I will have found a lower bound on the costs of corruption and of moving a headquarters. 


\section{DATA AND VARIABLES}

My initial dataset includes all U.S. firms (i.e. survivors and non-survivors) in the Compustat North America Fundamentals Annual file from 1980-2009 that have headquarters location information. Headquarters location is critical in assigning firms to district courts so that I can link firms to the corruption figures. I delete firm-years that have negative assets or sales and follow convention in setting missing research and development expense (R\&D) to zero and including an indicator to note a missing R\&D observation. Apart from a few robustness tests, I exclude financial firms (Standard Industrial Classification (SIC) codes 6000-6999) and utilities (SIC 4900-4999) because of both strict federally-mandated liquidity and, in the case of financials, because holding liquid assets is part of their operations. After deleting observations without the required accounting data, this leaves an unbalanced panel of 117,410 firm-years in 14,044 unique firms.

Previous empirical work uses several definitions of the cash ratio. Throughout my analysis I use the conventional (and simplest) to facilitate ease of interpretation: cash and cash equivalents divided by total assets. Using assets net of cash avoids some of the econometric problems of scaling both the dependent variable and some independent variables by assets. However, this creates extremely large outliers because some firms (e.g., Microsoft and Google) carry substantial cash ratios; this necessitates logging the cash-to-net-assets ratio, which is another common measure of a 
firm's cash ratio. Because all of the liquidity results using the $\log$ (cash/net assets) measure are statistically significant with generally larger effect sizes, I only report results using the cash ratio.

For leverage, I use debt in current liabilities plus long-term debt over assets, or book leverage.

\section{A. CORRUPTION}

In this paper, I follow the literature and link the corruption a firm faces in its operations to that in the area of its headquarters. ${ }^{9}$ I use the yearly number of corruption convictions from each federal judicial district (I use this term and district court district interchangeably throughout) within the U.S. to create a panel dataset to proxy for underlying corruption. ${ }^{10}$ To match to corruption, I convert state-county observations provided by Compustat to their respective Federal Information Processing Standard (FIPS) codes and then hand-match FIPS codes to federal judicial districts. I match convictions to contemporaneous financial data. ${ }^{11}$

The U.S. Department of Justice (DOJ) Public Integrity Section (PIN) maintains the data on public corruption convictions. The DOJ releases yearly conviction numbers for the 94 U.S. district court districts in its "Report to Congress on the Activities and Operations of the Public Integrity Section." Most numbers in the report are convictions prosecuted by the U.S. attorney's

\footnotetext{
${ }^{9}$ I exploit firm differences in headquarter importance in robustness tests in Section V.

${ }^{10}$ In rare cases, there is a missing conviction number for a district-year; in these cases, I use the average of the adjacent years as the conviction figure for the missing observation.

${ }^{11}$ Although lagging generally provides a more causal inference, I find it unnecessary for several reasons. First, because my data measure convictions rather than indictments, these are necessarily several years removed from when the crimes occurred as it takes time to build a case and conduct a trial. Second, district corruption is sticky. That is, it appears that corruption cannot be "rooted out" quickly, and persists over long periods. Nevertheless, using lagged measures does not change my conclusions.
} 
office in the district in which the case originated (districts follow state and, in the case of multidistrict states, county lines), sometimes with operational support by PIN, though PIN directly handles approximately 2,000 cases per year (see Glaeser and Saks (2006) for a further discussion). Corruption investigations by and reported to PIN are for crimes including bribery, extortion, election crimes, and criminal conflicts of interest. Refer to Figure 1 for examples of cases handled directly by PIN from several of its annual reports to Congress.

Unfortunately, because PIN does not summarize all conviction cases, I am unable to count only those convictions that we might expect to plausibly affect the firm. That is, included in the variable are offenses not likely to directly impact the firm, e.g., election crimes or other crimes of a strictly political nature. My analysis assumes that the various types of corruption are positively correlated, such that a district with a high number of convictions has a culture of corruption that should impact firm operation in the district. In the end, it is important to note that the conviction data are a proxy for the actual level of corruption in a district. The likelihood of measurement error that results in serious biases in estimation (e.g., when greater underlying corruption implies lower observed convictions) is discussed below.

Both the finance and economics literature use this measure. For example, Glaeser and Saks (2006), Butler et al. (2009), and Fisman and Gatti (2002) use these data. The authors that have used this measure of corruption have noted the superiority of "hard" data over measures that rely upon surveys because the data are standardized, verifiable, not based on opinion, and allow the creation of a panel. 
An advantage of my data in particular is the use of federal judicial district-, as opposed to state-, level data. ${ }^{12}$ Allowing within-state variation - for example, comparing companies in Northern Illinois to companies in Central Illinois - should add considerable power to the analysis, because these districts face similar tax codes and economic environments but different levels of corruption. U.S. district court districts follow county lines and have remained unchanged since 1978. As is common, I standardize the number of convictions in each district by population estimates from the U.S. Census, summing the county data into their respective districts through FIPS codes (Fisman and Gatti (2002), Glaeser and Saks (2006) also scale by population). ${ }^{13}$

One important concern is that the areas with few corruption convictions may be most corrupt, but the offenders are escaping detection or indictment. This lack of oversight could stem from a corruption of the justice system or some districts having better attorneys, better law enforcement, or more resources. Several points should help recommend convictions as a reasonable proxy. First, as direction, supervision, and assistance flow from a federal department, I expect at least moderate homogeneity of enforcement. Second, Boylan and Long (2003) find that the number of state-level convictions is positively correlated with the perception of corruption by state house reporters. Third, as will be shown in Table 1, conviction numbers line up well with intuition and pre-conceived notions about the most and least corrupt areas in the U.S. Lastly, using an alternative survey measure of corruption to address exactly this concern does not alter my conclusions.

\footnotetext{
${ }^{12}$ Completing the analyses at the state level in general yields weaker statistical significance and lower magnitudes, but does not alter my overall conclusions.

13 Alternatively, scaling by some measure of economic activity, such as the number of firms in each districtyear, gives very similar results.
} 
The alternative measure is a cross-sectional state level measure recently made available by the Center for Public Integrity through the State Integrity Project. It offers an alternative to convictions that alleviates concerns about measuring underlying corruption with conviction data by addressing likelihood of conviction:

$[T]$ he State Integrity Investigation takes a different approach by measuring the risks of corruption, as reflected in the strength or weakness of laws, policies, and procedures designed to assure transparency and accountability in state government.

Using a combination of on-the-ground investigative reporting and original data collection and analysis, the State Integrity Index researched 330 "Integrity Indicators" across 14 categories of state government: public access to information, political financing, executive accountability, legislative accountability, judicial accountability, state budget processes, civil service management, procurement, internal auditing, lobbying disclosure, pension fund management, ethics enforcement, insurance commissions, and redistricting. ${ }^{14}$

These integrity indicators cover both the laws that are on the books as well as measured enforcement of those laws. I invert the scale so that a higher number corresponds to a more corrupt state.

One could argue that the number of corruption indictments, rather than convictions, may be a clearer measure of the overall corruption in an area (by avoiding the issue of connected officials escaping conviction). However, two points should alleviate any concern. First, the overall conviction rate is high: approximately $86 \%$ for the sample period. Second, Butler et al. (2009) find that the correlation between current charges (offered nationally) and convictions is also high (0.72 to 0.77) and, when included together with current charges, lagged charges are not significantly related to convictions.

${ }^{14}$ http://www.iwatchnews.org/2012/03/19/8423/grading-nation-how-accountable-your-state 
Another potential concern is reverse causality. However, that does not appear to be an issue in this study. First, it is unclear why corruption would center on areas in which the average firm has low cash holdings. Second, though it is plausible to assume corruption centers around areas with high cash firms, I do not find a positive relation between corruption and cash holdings.

Table 1 contains summary statistics for each U.S. district court district-year included in my sample prior to dropping utilities, financials, and observations with missing accounting data (i.e., later analyses use a subset of these data). Because I restrict my focus to U.S. firms, the districts of the four territories (Guam, Puerto Rico, the Virgin Islands, and the Northern Mariana Islands) are not included. This leaves me with 90 districts in 50 states and the District of Columbia, all of which have a presence in the sample.

I report the number of firm-years in each district, as well the median, mean, standard deviation, minimum, and maximum of convictions per 100,000 for each district in Table 1 . The number of convictions per 100,000 varies greatly between districts, with a median of 5.368 in Washington D.C., to 0 in Northern West Virginia. It is perhaps unsurprising that Washington D.C. tops the sample by such a large margin (the next largest median is 1.239 in Western Tennessee). The difference is most likely because D.C. serves as a political center and has fewer inhabitants than the districts that span part or all of a state. Because of these large differences in per capita corruption at both the top and bottom of the sample I winsorize per capita corruption at the $1 \%$ and 
99\% levels. ${ }^{15}$ Most tests in the analysis use this continuous variable per capita corruption. However, for univariate tests in which the level of observation is the firm, I classify a district as corrupt if its median per capita corruption figure is in the top quartile of per capita corruption convictions. That is, I take the median of the time series of convictions for each district, and then if a district median falls in the top (bottom) quartile of the cross-sectional medians, I classify it as corrupt (non-corrupt). In general, the Table indicates that utilizing the cross-sectional variation is important, as there are big differences in the average level of corruption faced by firms across districts. Further, in an unreported analysis, I find that although there is time series variation within districts, the ordering of most corrupt to least corrupt district stays relatively stable from year to year. Because of this stickiness in corruption, the ordering of the districts is not very sensitive to the time period covered.

The table also shows, however, that there is substantial time series variation in the number of corruption convictions as can be seen in the standard deviations and minimum and maximum for each district. For example, the standard deviations for the top third most corrupt districts tend to be above 0.490 (greater than the sample-wide standard deviation of 0.349 ) and the range tends to be above 1.0. A regression of per capita corruption on indicators for each district indicates that $52 \%$ of the variation in convictions is explained cross-sectionally, while the rest is time series variation. Using the within-district variation will also be an important piece of the analysis.

\footnotetext{
${ }^{15}$ Without winsorizing, the results are generally of slightly smaller economic magnitude and model fit is slightly worse. Trimming the data or just dropping Washington D.C. provides nearly identical results.
} 
Figure 2 provides a visual representation of the conviction data in Table 1. I use the median of convictions per 100,000 for each district. I plot these median data in the choropleth map with the five breaks shown in the legend, designed to have approximately 15 districts in each category. Figure 2 highlights the variation in corruption that exists within some states such as Tennessee, California, and Florida and indicates that district-level analysis is likely important.

\section{B. CONTROLS}

I defer the discussion of individual controls to the discussion of results (Section IV.B), in which I detail the controls as I discuss the models. I include all variable definitions in the Appendix.

In order to guard against the effect of outliers on my results, I winsorize all firm ratio variables at the $1 \%$ and $99 \%$ levels. For comparison with other studies, Table 2 contains summary statistics for the control variables as well as the variables of interest.

Compustat provides state and county of headquarters for approximately $70 \%$ of observations. In comparing summary values between firms that do and do not have headquarters data, those firms missing headquarters data tend to be smaller, less levered, and have higher market-to-book values and cash balances. However, when I match on size and industry, most of the differences go away, suggesting that these growth firms without headquarters data look similar to the growth 
firms in my sample, but that Compustat has neglected collecting headquarters data for these

firms. ${ }^{16}$ Therefore, I do not expect a selection bias to influence the results.

${ }^{16}$ This is somewhat of a moot point. If I reverse my data screening, instead first deleting observations missing any of the necessary accounting data, financials, and utilities (together these filters drop more than 90,000 firm-years), and removing observations missing headquarters data afterward, this headquarters filter only deletes 7,485 firm-years. 


\section{RESULTS: THE ASSOCIATION BETWEEN CORRUPTION AND FI- NANCIAL POLICY}

\section{A. UNIVARIATE ANALYSIS}

Table 3 shows the results of the univariate analysis. Analysis is at the firm level done by taking the median value of each variable for the firm. Conducting the analysis at this level avoids the interpretive issues caused by a very large sample size with the same firm repeated in many yearly observations, although results are similar using firm-years. Panel A displays the means and medians (of the firm medians) by corrupt and non-corrupt districts. The mean (median) cash ratio is 8.72 (6.97) percentage points lower for a firm with headquarters in a corrupt district than for another in a non-corrupt district. Leverage is 7.46 percentage points lower at the median in a noncorrupt district. The leverage mean is actually lower for firms in corrupt districts, but the difference is not statistically significant. The median market-to-book is $15.95 \%$ higher in non-corrupt districts. The differences are highly statistically significant for all rank-sum tests and for the ttests for the cash ratio and log of cash-to-net assets.

In Panel B, to provide a better comparison of the variables and establish some of the robustness of the relations, I match the corrupt and non-corrupt firms on size and industry. Cash has 
been found to vary systematically by size and industry, so matching absorbs some of this variation (Gao, Harford, and Li (2013)). Specifically, I match firms in the same 3-digit industry that are closest in size (the match firm must be within $50 \%$ and $150 \%$ of assets) with replacement. Despite matching, Panel B shows the differences in the variables persist, albeit with diminished magnitude; cash and market-to-book continue to be higher and leverage lower for firms with headquarters in corrupt districts. The differences in cash and leverage are 4.17 (3.04) and 2.96 (2.62) percentage points at the mean (median), respectively, with firms in corrupt districts holdings less cash and more leverage. All rank-sum test statistics are significant and all but the market-to-book difference of means tests are significant.

\section{B. MULTIVARIATE ANALYSIS OF CASH HOLDINGS}

Table 4 displays the results of regressions using cash-to-assets as the dependent variable. In all models except Model (4), I cluster standard the errors by both time and firm to ensure robustness to unspecified time and firm correlations in the standard errors, which could be present in panel data (Petersen (2009)). Model (4) uses the Fama-MacBeth regression method with Newey-West (1987) standard errors set to the maximum lag length to limit the impact of any autocorrelation in the standard errors.

In all of these models, the corruption measure is negatively related to cash holdings. The coefficients are significant at the $1 \%$ level in all models except the Fama-MacBeth model coefficient, which is significant at the $5 \%$ level. The relation is robust to using alternative measures from the 
literature. The adjusted R-squared of these base models ranges from $35.7 \%$ to $43.7 \%$, depending on the exact specification. In unreported analyses I conduct these tests using the firm as the level of observation (instead of firm-year) by taking time-series medians and results are largely unchanged.

Models 1, 2, and 3 are pooled OLS models with year and industry fixed effects in Models 2 and 3. ${ }^{17}$ Model 3 adds foreign sales and net debt and equity issues, variables that Bates et al. (2009) found to be important in determining the cash ratio, but that greatly reduce the sample size because they are less frequently populated in Compustat. In Models 2 and 3, given the industry and time dummies, the results indicate that corruption is negatively correlated with cash holdings considering firms in the same industry (2-digit SIC) in the same year. These results suggest that geographically captive industries, such as logging, mining, drilling, etc., do not drive this association.

In Models 5 and 6 I use the alternative measure of corruption from the State Integrity Investigation for robustness. In both Models the coefficients are negative and significant at the $1 \%$ level. Although the State Integrity Investigation just recently compiled the measure, I use it for the years 2000-2009. The results are similar if I use it for 2009 only or for all 30 years of the sample; the invariance of the results to time period is a further testament to the stability of cultures of corruption.

\footnotetext{
${ }^{17}$ Including fixed effects is the best method for controlling for unobserved heterogeneity, though if I industry-adjust (subtract industry-year medians from all variables in the model) instead, the results are quite similar (Gormley and Matsa (2014)). The results when including higher dimensional fixed effects (e.g., industry-year), are also quite similar to those reported.
} 
To assess economic significance, I look at the difference between a hypothetical firm with headquarters in Northern Illinois, which is highly corrupt (Chicago is in this district), and a firm in Central Illinois, which has low corruption. The difference between the district medians is roughly one standard deviation, using the sample-wide measure. ${ }^{18}$ The association I find is large in magnitude. The firm headquartered in Northern Illinois holds a cash ratio between 63 and 78 basis points lower than the firm in Central Illinois, all else equal. With a sample average (median) cash ratio of $16.8 \%(7.8 \%)$, this is a $3.75 \%(8.08 \%)$ to $4.65 \%(10.0 \%)$ change from the sample average (median). The survey corruption measure indicates a larger magnitude, with a one standard deviation change in it corresponding to approximately a 1.7 percentage point change in the cash ratio, or $10.12 \%(21.79 \%)$ of the mean (median).

In addition, convictions and the survey data measure slightly different elements of corruption; convictions measure the enforcement of the law and the survey grade measures the strength of the state laws and institutions (and to some degree, a judgment of how they are enforced). In other words, they measure the actual incidence of and the threat of corruption. Thus, the real effect of corruption could be some combination of these effects. When both convictions and the survey measure are included they have coefficients of -0.015 and -0.001 , respectively, with t-statistics above 4 (unreported).

I draw my controls from existing research on the determinants of cash holdings (e.g., Opler et al. (1999), Bates et al. (2009), and Haushalter, Klasa, and Maxwell (2007)). The controls have

\footnotetext{
${ }^{18}$ The district medians for Northern and Central Illinois are 0.555 and 0.183 , respectively. The sample-wide standard deviation for convictions is 0.349 .
} 
the expected signs and are stable throughout the analysis. Market-to-book, cash flow, R\&D expense, industry cash flow risk, the negative net income dummy, and net debt and equity issues are all positively related to firm cash holdings. Industry HHI, leverage, net working capital, capital expenditures, size, acquisitions, the dividend dummy, the indicator for a missing R\&D value, and the number of firm business segments are all negatively related to firm cash holdings. These results are consistent with prior literature. ${ }^{19}$

Overall, the results from Table 4 show that corruption is negatively and significantly related to the cash ratio of sample firms. This is consistent with the hypothesis that firms reduce liquidity in the face of rent-seeking behavior by local public officials.

\section{MULTIVARIATE ANALYSIS OF LEVERAGE}

In this section, I test how corruption affects leverage. I expect firms to increase leverage when their headquarters is in a corrupt district to deter government expropriation by increasing the risk of bankruptcy. This effect is akin to Matsa (2010), who finds that firms facing a strongly unionized labor force tend to make more extensive use of debt financing, and suggests the result fits with prior theoretical models that this is to strategically increase the probability of bankruptcy as well as increase the volatility of the firm's profit stream, reducing perceived surplus.

\footnotetext{
${ }^{19}$ Readers familiar with Haushalter, Klasa, and Maxwell (2007) may recall that using HHI from the Census Bureau, they find a positive relation between cash and HHI. This seems to be due to the presence of private firms. Although Ali, Klasa, and Yeung (2009) find bias in using Compustat instead of Census HHI, the relation between corruption and cash holdings is invariant to my choice of HHI. I choose the Compustat HHI to maximize the sample size and the generality of my conclusions.
} 
Table 5 displays results from regressing leverage on convictions per 100,000 and various financial controls from Matsa (2010). Model 1 is the base specification. The 2-digit SIC and year dummies in Model 2 again compare firms in the same industry and year. Model 3 uses a FamaMacBeth regression and Models 4 and 5 use the survey measure of corruption. I cluster standard errors by both firm and time in the first four models and by firm in the Fama-MacBeth model, which uses Newey-West standard errors.

The coefficient on convictions per 100,000 is significant at the $1 \%$ level in all models. The magnitudes of the coefficients indicate that a firm with headquarters in Northern Illinois holds between 78 and 123 basis points, or between $2.74 \%(3.63 \%)$ and $4.32 \%(5.72 \%)$ of the mean (median), more leverage than a firm in Central Illinois, all else equal. The magnitude of the relation is again larger for the survey variable, implying a 1.71 percentage point change in leverage or $5.96 \%(7.91 \%)$ of the mean (median) for a standard deviation change in the measure. Including both measures of corruption in the same regression does not diminish statistical or economic significance of the coefficients, suggesting a larger total effect of both the threat and act of extortion (unreported).

The adjusted R-squared of the models ranges from $28.5 \%$ to $40.7 \%$. The models that use the alternative corruption measure have the best model fit. The included controls are mostly of the expected signs, though not all of them are statistically significant. Market-to-book; property, plant, and equipment (PP\&E); and sales are positively related to leverage. Modified Altman-Z and EBITDA are negatively related to leverage. Overall, these results indicate that firms with 
headquarters in more corrupt districts tend to have higher leverage, and are consistent with the hypothesis that firms restrict financial slack to limit expropriation.

\section{ANALYSIS OF FIRM PERFORMANCE AND VALUE}

On balance, it is unclear how the changes to firm financial policy impact firm performance and value. Up to this point, I cannot judge whether the financial policy changes are value-increasing or -decreasing. First, although expropriation through corruption is important, corruption is also potentially a reflection of at least some firms forging valuable political connections, such as in Goldman et al. (2009) and Borisov et al. (2012). These political connections may allow firms preferential access to debt or priority in bailouts (Claessens et al. (2008); Faccio et al. (2006)). Second, the literature is mixed as to how cash affects the firm. Some research has shown that high cash holdings can be value increasing, or at least not detrimental to firm performance (e.g., Mikkleson and Partch (2003)). If the average firm is indeed holding close to an optimal cash balance, then clearly any deviation caused by corruption is detrimental. However, Jensen (1986) suggests that less cash under management control along with more leverage may be beneficial to

firms. Additionally, other researchers have found that cash balances can be valued below their dollar value in some cases (Faulkender and Wang (2006)). So, one might argue that decreasing cash and increasing leverage may actually be beneficial to shareholders. To determine how these differences in financial policy might impact firms, I begin by examining operating and accounting performance in a univariate framework. 


\section{Performance}

In Table 6, I repeat the type of analysis used in Table 3, classifying districts as corrupt (noncorrupt) if they are in the top (bottom) quartile of district convictions to examine univariate statistics. The level of observation is the firm, using the median value of each variable. Firms in corrupt districts are matched to firms in non-corrupt districts by size and 3-digit SIC industry. The Appendix provides variable definitions that show the Compustat mnemonic variables.

Panel A shows statistics for the entire matched sample. Firms headquartered in corrupt districts have lower return on book assets (ROA), operating income-to-assets (OCF), operating cash flow (statement of cash flows value (SoCF)) over assets, net income-to-assets (NI), and earnings before interest (EBI) over assets. Return on book equity (ROE) is significantly lower for firms headquartered outside corrupt districts; in an unreported analysis, I find that this is driven not by higher earnings, but by systematically lower book equity in corrupt districts (which likely reflects the leverage choice). The magnitudes of the differences range from 6.0-26.5 (-1.1 to 0.4) percentage points for means (medians). Further, these differences represent significant percentages of the mean and median values. Although the point estimates suggest inferior performance, only two rank-sum tests are significant for ROE and OCF and most difference of means tests are outside $10 \%$ significance.

The relation between corruption and performance may be greater among financially constrained firms because of their demonstrated need for cash. Financially constrained firms are those firms whose internal funds are insufficient to fund all investment opportunities and whose 
access to outside capital is limited. Therefore, I expect that a decrease in the cash balance and an increase in debt payments related to corruption are particularly damaging to constrained firms, as financial flexibility deteriorates with the changes.

In Panels B - E, I explore these univariate relations within subsamples of financially constrained firms. I use the classification schemes commonly used in the literature (see, e.g., Almeida, Campello, and Weisbach (2004) and Denis and Sibilkov (2010)) to separate firms as constrained or unconstrained. I classify firms as constrained if they are in the bottom three deciles of size or payout ratio, or have never had their long-term debt or short-term commercial paper rated by Standard and Poor's Rating Agency. Analogously, firms are unconstrained when in the top three deciles of size or payout ratio, have had their long-term debt rated and it is not in default, or have had their short-term commercial paper rated and it is not in default.

In all of the panels, every accounting and performance mean value is larger for the firms in the non-corrupt districts relative to the means for firms headquartered in corrupt districts. The values differ anywhere from $25 \%$ for the NI values among firms classified as constrained by payout to $130 \%$ for the ROE values among firms classified as constrained by short-term paper. However, only a handful of these differences are statistically significant at the $10 \%$ level; most are concentrated in Panels D and E. The remaining t-statistics for the differences are all around 1.5, slightly below the threshold for statistical significance.

Across the four panels of constrained firms, seven of the 24 median numbers are lower for firms in non-corrupt districts, including all four ROE values. But once again there are only sever- 
al rank-sum test statistics that are statistically significant; in Panels B and C OCF (SoCF) is statistically greater for firms in non-corrupt districts. In general, these test statistics are all smaller than those for the differences of means tests.

\section{Firm Value}

Though the results in Table 6 are somewhat suggestive of inferior performance, the overall statistical significance is weak. Therefore, in Table 7 I take a more direct tack and examine the relation between corruption and firm value in a multivariate framework. I use the firm's market-tobook ratio as a proxy for firm value and draw on the extant literature for the control variables (see, e.g., Daines (2001)). The controls are real size, EBITDA, leverage, cash flow, firm age, a dummy for Delaware incorporation, R\&D, and intangible assets. These last two are to control for growth opportunities and give market-to-book more of a value interpretation. In these models I include year dummies and cluster standard errors by firm. Including industry dummies for various SIC levels does not substantively impact the analysis.

The first model in Table 7 is the base specification. Corruption is negatively and significantly related to market-to-book. ${ }^{20}$ This negative relation is consistent with the results in Brown, et al. (2013) and Garner, et al. (2012). The point estimate implies that a firm headquartered in North Illinois will have a mean (median) market-to-book $1.70 \%(2.90 \%)$ lower than a firm in Central Illinois, all else equal. Although this may seem trivial, this translates to a change in the market

${ }^{20}$ In an unreported analysis, I find that, conditional on operating in a corrupt district, this negative relation between corruption and value is exacerbated when firms hold excess cash (defined as cash above that predicted by my baseline model, excluding the corruption variable) or excessively low leverage (defined similarly). 
value of equity of $4.17 \%$ of book assets. For the median firm in the sample, this is a $\$ 4.32$ million reduction in market value. If firms shielding assets as a result of corruption leads to this decrease, then it suggests that moving a headquarters or paying bribes costs strictly more than this for most firms. In the last four models, I again focus on financially constrained firms, as the financial policy changes may have a greater impact on them. Each column represents an alternative classification scheme, and includes a constrained indicator and its interaction with per capita corruption. Although in three of these four samples corruption is still negatively and significantly related to market-to-book (short-term paper ratings is the exception) none of the interaction terms is statistically significant.

Coefficients on control variables are generally as expected. Larger, older firms with greater cash flow (which likely reflects operation in a mature industry) tend to have lower market-tobook. Firms that have more intangible assets, more R\&D expense, greater EBITDA, and are incorporated in DE tend to have higher market-to-book. Leverage is unreliably related to marketto-book. $^{21}$

On the surface, my results are consistent with a world in which firms that are high obligation (interest and dividends) and low liquidity are currently poor performing (for whatever reason) and they seek to bribe politicians as a last resort. This leads to a high number of convictions in a district. I find this less plausible than the shielding assets explanation because corruption is measured geographically and is very persistent. For example, the districts of Washington D.C., West-

\footnotetext{
${ }^{21}$ Using a median regression, leverage is negatively related to market-to-book in all of the models.
} 
ern Tennessee, and Eastern Louisiana rank in the top quartile of convictions in 30, 29, and 23 years of the sample, respectively. If certain districts systematically induce poor performance it appears firms would not survive and eventually new firms would not locate there to avoid the economic conditions perpetually causing poor performance. However, the expropriation interpretation of the results allows for the benefits to locating in a corrupt district to outweigh the costs (i.e., poor performance is not a certainty). The negative associations between corruption convictions and firm value and operating performance demonstrated here and elsewhere in the literature are also difficult to square with other bribery stories in which firms are willing participants in corruption.

One alternative approach is to use any conviction dates available in PIN's report to Congress as a natural experiment. However, there are at least three major concerns with this approach. First, this immediately introduces a selection bias as only some cases are detailed. Second, there would only be a measured effect if the conviction provides new information to the market. Third, a significant challenge resides in the long-run persistence of corruption, which suggests that it is the political position and environment not the individual politician (e.g., again, the Chicago Way). In spite of these challenges I explore traditional event study results using these conviction dates to see how firms in the relevant districts are affected. Because these tests yield few significant results, I do not report them. 


\section{ROBUSTNESS: DOES CORRUPTION CAUSE CHANGES TO FINANCIAL POLICY?}

Despite the many control variables included in the multivariate tests, it is, nevertheless possible, that my findings are spurious because of an omitted variable or variables that could drive the associations between convictions and the financial policy variables and firm value. Corruption is deep-rooted in certain areas (which may not conform to district lines) and has many covariates. Education, local attitudes toward corruption, or other issues could drive the foregoing results. In this section I address endogeneity concerns through several avenues including fixed effects, an instrumental variables (IV) approach, and subsample analyses. ${ }^{22}$

\section{A. ALTERNATIVE SPECIFICATIONS}

In Tables 8 and 9, I run alternative models for the cash ratio and leverage, respectively. All of the variables from the previous section are included, but omitted for brevity. In these tables, I again cluster standard errors by both firm and time, except in the IV models, in which I cluster standard errors by firm.

\footnotetext{
${ }^{22}$ Brown et al. (2012) thoroughly explore the relation between firm value and corruption and Garner et al.
} (2012) also cover it, therefore, I focus my robustness checks on the cash ratio and leverage models. 
The first three models in Table 8 take advantage of the substantial time series variation in per capita corruption. Models 1 and 2 are one- and two-year changes, respectively, which include all variables (including the cash ratio and leverage) as one- and two-year changes. These models remove time invariant omitted effects and show how cash varies as corruption varies. The coefficients on corruption in Models 1 and 2 with the cash ratio as the dependent variable are -0.003 and -0.006 and are significant at the $5 \%$ and $1 \%$ levels, respectively. Model 3 estimates the regressions with firm fixed effects. The coefficient on convictions per 100,000 in the cash model is 0.007 and significant at the $1 \%$ level. The coefficient on convictions per 100,000 in the leverage model is 0.009 and significant at the $5 \%$ level. These models wipe out any cross-sectional variation, and focus on within-firm variation. Thus, these specifications indicate that for a given firm, more per capita convictions is related to a lower cash ratio. Further, these results indicate that there is both a level (cross-sectional) effect across districts, as well as a within firm effect as firms adjust to changes in corruption. For example, a firm in southern Florida (median convictions per 100,000 of 0.965) might always carry less cash than a similar firm in northern California (median of 0.103 ), but both firms might adjust cash holdings as corruption in the district changes (which, as shown in Table 1, it appears is often). If these effects are indeed joint then the combined point estimates in both the cross-sectional tables and the models in this table point to an even larger effect on financial policy.

The next three models (Models 4-6) in Table 8 address the omitted variable problem directly by including several additional variables that are related to cash or corruption, but that reduce the sample size. In Model 4, I include industry unionization rate, which previous work has found 
to be an important determinant of the cash ratio (Klasa et al. (2009)). I use the publicly available industry unionization data from the Union Membership and Coverage Database for 19832009. ${ }^{23}$ The data are defined by Census Industry Classification, which I convert to SIC codes before 2002 and North America Industry Classification System (NAICS) codes after 2002. I also include inventory, which explains some of the variation in cash holdings (Kulchania and Thomas (2013)). Unionization and inventory are negatively related to the cash ratio, consistent with existing literature. After including these two variables, the coefficient on corruption is not far from the baseline regressions: -0.016 and statistically significant at the $1 \%$ level. In Model 5 , I add product market fluidity. ${ }^{24}$ Hoberg et al. (2014) develop fluidity from firm 10-k filings, and define it as product market threats and instability generated by rival firms. They find that fluidity is robustly related to cash holdings: firms with more rival threats in their product market space hold more cash. The coefficient on corruption in this model is -0.018 and statistically significant at the $1 \%$ level. Fluidity enters positively, but the coefficient in my regressions is only one third the magnitude of that in Hoberg et al. (2014), 0.015 compared to 0.045. In Model 6, I include variables that may influence the level of corruption (or are at least correlated with it, see Glaeser and Saks (2006)), per capita income growth, unemployment, and educational attainment. The U.S. Census Bureau measures both per capita income and unemployment at the county level, and educational attainment, the percentage of the state population with a Bachelor's degree, at the state level. Educational attainment is available only sparingly before 2000, and limits the sample size. Inclu-

\footnotetext{
23 These data are maintained at www.unionstats.com by Barry Hirsch and David Macpherson. See Hirsch and Macpherson (2003) for details of data construction.

24 The product market fluidity data are available from the Hoberg and Phillips Data Library, http://alex2.umd.edu/industrydata/.
} 
sion of these economic variables increases the magnitude of the coefficient on corruption to -0.028, and it remains statistically significant at the $1 \%$ level. $^{25}$

In the last model I use an instrumental variables approach. The instrument I use is the concentration of a state population around its capital city measured by the Gravity-Based Centered Index for Spatial Concentration (GCISC) from Campante and Do (2010). ${ }^{26}$ I use the version of the measure adjusted for state size and shape; the measure ranges from 0 to 1 , where 0 corresponds to a situation in which everyone in the state lives as far from the capital as is possible and 1 would indicate that the everyone lived in the capital. Campante and Do (2012) develop the econometric and theoretical underpinnings of the measure: they find that isolated capital cities are associated with more state corruption, which they argue is because there is less oversight by the electorate. In the first stage regressions (unreported) the isolation of the capital city is directly related to state corruption; the concentration of the state population is not a weak instrument. In fact, the first stage F-statistics that are used to test the null that the instruments are weak greatly exceed the oft used threshold of 10 and are larger than the Stock and Yogo (2005) critical values. Campante and Do (2012) calculate GCISC for every U.S. Census year; I match fiscal years $t+1$ through $t+10$ (i.e., to financial variables that occur strictly after measurement of the spatial concentration of the population) to a single GCISC value to limit the potential for reverse causality.

\footnotetext{
${ }^{25}$ Running my baseline regressions for only those firm-years for which these data are available yields results that are quite similar to those in the main tables.

${ }^{26}$ I thank Filipe Campante and Quoc-Anh Do for generously sharing these data.
} 
In order to be a valid instrument, capital city isolation must also satisfy the exclusion restriction, that is, isolation must act on the cash ratio and leverage only through the relation with state level corruption. This seems plausible. It is unclear how population density around a state capital would influence a firm's financial policies.

In Table 8, in the second stage the coefficient on the instrumented value of corruption is -0.009 and not statistically significant. However, a Hausman test does not reject the null hypothesis that corruption is exogenous in the cash models. The insignificance seems to be driven by larger standard errors in IV estimation, as the standard error is more than seven times larger than that from the OLS regressions.

In Table 9, with the exception of the model that uses product market fluidity, I duplicate the regressions from Table 8, but use leverage as the dependent variable. In Models 1 and 2, one and two-year changes, coefficients are insignificant in the leverage models. It is possible that firms do not rapidly update leverage as corruption changes, whereas there are lower transaction costs to quickly altering the cash ratio. However, corruption is positive and significant in the firm fixed effect model. This indicates that within the firm, leverage does respond to changes in corruption. As with the cash models, the total effect is likely some combination of the within and between results. In Model 4, I again include industry unionization rate because Matsa (2010) finds that firms use leverage in response to unionization (inventory is not included in this model). Model 5 is also an extended specification, which includes income, educational attainment, and unemployment. In both models, after including unionization or the economic variables, the relation be- 
tween corruption and leverage strengthens, with a slightly larger coefficient and increased tstatistic from the baseline. The last model in Table 9 is also the second stage regression from the IV estimation; instrumented corruption is positively and significantly related to leverage. The coefficient in the IV model is 0.153. A one standard deviation increase in corruption implies an $10.58 \%(14.02 \%)$ change from the mean (median) leverage value.

Together, the results from Tables 8 and 9 rule out the possibility that some existing explanations are responsible for the observed relations between corruption and financial policy. Further, the change models, inclusion of firm fixed effects, and IV estimation collectively begin to cast doubt on alternative explanations that are not already documented in the literature, because the omitted effect must be both time-varying and correlated with the concentration of the state population around the capital (the latter at least for leverage). 


\section{B. SUBSAMPLE ANALYSIS}

In Table 10 Panel A (B), I rerun the base cash ratio (leverage) regressions in various subsamples in which corruption should have a differential impact. Each column includes a different indicator or continuous firm characteristic variable. In this table, I use an indicator equal to 1 (0) if a district is in the top (bottom) quartile of corruption convictions in a given year to measure corruption. I prefer an indicator to the convictions per capita number because it simplifies the interpretation of the interaction terms. ${ }^{27}$ As in the previous tables, standard errors are clustered by firm and fiscal year. I omit the controls for brevity.

The first model in each panel is a baseline specification for reference. These models confirm that corruption is still negatively (positively) related to cash (leverage) using an indicator. In the second model I run the regressions with financial firms (SIC 6000-6999) and utilities (4900-4999) included and with an indicator equal to 1 for these firms. Given the heavy regulation and oversight faced by these firms, I would expect corruption to have no effect on them. First, there is likely a significant benefit to dealing with corrupt politicians for these and so they would not change policies to limit ability to pay. Second, were they to reorganize financial policies, corrupt politicians could more easily punish firms that refuse to pay with further regulation. The results are consistent with this interpretation. The coefficients on the interaction terms, corrupt indicator times financial and utility indicator, in both models are opposite the coefficient on the indicator alone. In the cash regression the interaction term is 0.022 significant at the $10 \%$ level, undoing the

\footnotetext{
${ }^{27}$ The results are qualitatively similar if I use convictions and mean-center the continuous interaction terms.
} 
-0.021 coefficient on corruption. In the leverage regression the coefficient is -0.057 and highly significant. This could suggest that utilities are, together with corrupt officials, increasing their equity so that they can raise the prices charged (which are based on an ROE calculation). Ultimately, it appears regulated industries do not behave in the same manner as unregulated industries when faced with corruption.

In the next model I run the regressions with an interaction for the corrupt indicator and size. Smaller firms are likely more susceptible to extortion from corrupt officials because of less developed legal teams, little or no lobbying presence, and less economic importance (less disincentive for politicians to bankrupt these firms). The coefficient on the interaction term in the cash ratio regression is -0.002 , significant at the $5 \%$ level. The interaction term suggests that when operating in a corrupt district, larger firms carry less cash than smaller firms. This is the opposite of the expected result. In the leverage regressions, the coefficient on the interaction is approximately 0 and statistically insignificant.

In the next two models, I examine how the geographic concentration of firm operations affects the relations between corruption and the financial policy variables. Headquarters has more meaning for some firms than it does others. For example, Yum Brands is headquartered in Louisville, KY with the KFC division, but it also owns Taco Bell and Pizza Hut, which are headquartered in Irvine, CA and Plano, TX, respectively. Therefore, it is unclear exactly how (or whether) corrupt officials in Louisville impact the overall decision making at the firm level. Similarly, some firms may not operate in the area of their headquarters at all (e.g., Murphy Oil Corp.). Again, it is un- 
clear how (or whether) corruption around the headquarters would affect the firm. Because I match firms to corruption numbers based upon their headquarters location, it is critical to examine how these differences might impact the observed relations. To measure geographic concentration, I use the data from Garcia and Norli (2012): the number of states and the number of times each state is mentioned in a firm's 10-k from 1994-2008. ${ }^{28}$ I use both the count of states in which a firm operates as well as the relative importance (relative mentions) of the firm's home state (i.e., the state of its headquarters) to define geographic concentration. ${ }^{29}$

The distribution of state count is highly right-skewed, ranging from 1 to 50, with a median of 5; therefore, I winsorize at the $99 \%$ level. In the fourth column of both panels, I estimate the cash and leverage regressions adding state count and the interaction between state count and the corruption indicator. The coefficient on the interaction term in the cash ratio regression is 0.001 and significant at the $5 \%$ level. In the leverage regression in Panel B, the coefficient on the interaction is -0.002 and significant at the $1 \%$ level. Both results indicate that for firms headquartered in a corrupt district, operating in a fewer number of states exacerbates the relations between corruption and cash and corruption and leverage. For example, for a firm that operates in 1 state increases its leverage by 6.1 percentage points - a $21.40 \%$ change from the sample mean — when headquartered in a corrupt district, while a firm that operates in 20 states only increases leverage by 2.3 percentage points - an $8.07 \%$ change. The signs on state count in the two panels indicate

\footnotetext{
${ }^{28}$ I thank Diego García and Øyvind Norli for generously sharing these data.

${ }^{29}$ In an unreported test, I use these data to create a weighted average corruption measure based on the percentage of firm operations in state $k$, year $t$, times the corruption also in $k$, and $t$. The results are consistent with those reported in the tables.
} 
that firms that operate in few states hold more cash and less debt relative to those firms operating in many states.

In the final model I use the relative importance of the state in which a firm has its headquarters, roughly the percentage of the firm's operations in its home state. This measure ranges from 0 (the firm does not operate in its home state) to 1 (all the state's operations lie in its home state). In both the cash ratio and leverage specifications the interaction term shares its sign with convictions: in the cash regression the coefficient is -0.060 , significant at the $1 \%$ level, and in the leverage regression it is 0.049 , significant at the $10 \%$ level. The coefficient on the interaction from the cash regression indicates that a firm that operates entirely in its home state and faces a corrupt political environment holds 6.0 percentage points less cash as a proportion of assets. In the same regression the insignificant coefficient of -0.001 on the corruption indicator has a natural interpretation: corruption around the headquarters does change a firm's cash policy if it does not operate in its home state. The results confirm that corruption has a greater impact for firms that operate more heavily around their headquarters. The signs on concentration of operations indicate that firms with more geographic diversity in their operations hold less cash and more debt.

The tests of this section take several approaches to tackle endogeneity and are designed to establish a causal link, running from corruption to firm financing choices. The cash ratio is negatively related to corruption in change and fixed effects models and varies predictably in various subsamples. Although the instrumented value of corruption is not significantly related to the cash ratio, a Hausman test cannot reject exogeneity of corruption convictions. Leverage is positively 
related to corruption in the fixed effects and IV models, and the relation varies predictably in various subsamples. Therefore, alternative explanations must encompass not only the relation between convictions and financial policy variables, but also must be correlated with geographic concentration, the isolation of the capital city of a firm's state, and must differentially impact financials and utilities. Overall, the results of this section are consistent with causal relations between corruption, the cash ratio, and leverage. 


\section{CONCLUSION}

In this paper I investigate how the corruption of U.S. public officials relates to firm financial policies. Previously, most studies on corruption have been limited internationally due to data concerns. This prevented researchers from holding all national characteristics constant, as well as making it unclear what relations we might observe in nations ranking as non-corrupt whose strong rule of law may prevent corrupt officials from impacting firms.

I document a robust negative relation between corruption convictions and cash holdings. This relationship is economically meaningful. Firms with headquarters in the highly corrupt district of Northern Illinois and the low corruption district of Central Illinois have a difference in the cash ratio of approximately 0.71 percentage points, or $4.23 \%(9.10 \%)$ of the mean (median) cash ratio, all else equal. This result is consistent with the notion that firms manage liquidity downward in to limit payments to corrupt politicians.

Next, I consider whether firms in corrupt districts increase their debt service obligations to both limit FCF and increase profit variability (see Matsa (2010) for union-related evidence). Corruption convictions are positively and significantly related to leverage. Firms in Northern and Central Illinois have an approximately 1.01 percentage point difference in leverage, a $3.54 \%$ 
$(4.70 \%)$ increase from mean (median) ratio. This likely makes the liquidity reduction more credible, as it raises the specter of bankruptcy (and a possible vote out of office) with government expropriation.

Endogeneity represents an important obstacle in the interpretation of the base specifications. I attempt to address this in a variety of ways. First, I use an alternative measure of corruption that grades states on the strength of anti-corruption laws and institutions. Second, I use one- and two-year change models and firm fixed effects to remove time invariant omitted effects. Third, I include of some additional variables, for example industry unionization, per capita income growth. Fourth, I use an instrumental variables approach using the concentration of a state's population around its capital city as an instrument for state-level corruption. Lastly, I use subsample analyses: I find the effects are strongest among firms that operate mostly in the area of their headquarters. Collectively, the results of all of these tests suggest a causal relation between corruption and firm financial policies.

I next explore corruption and firm value, and I find that corruption is negatively related to market-to-book. A firm with headquarters in Northern Illinois will have a mean (median) marketto-book $1.70 \%(2.90 \%)$ lower than a firm with headquarters in Central Illinois, all else equal. This translates to a $4.17 \%$ of book assets loss of market value, or $\$ 4.32$ million for the median firm in the sample.

Ultimately, I conclude that the evidence is consistent with a world in which market frictions impact firm financial policy, but firm financial policy can be an important tool in reducing the 
effects of market fictions. I add to the streams of literature related to financial policy, as well as corruption, concluding that corruption acts as an external market friction, causing firms to deviate from first-best financial policies. These results can potentially explain why corruption is negatively related to economic growth, if firms are constrained by corruption. Future research could fruitfully explore more on U.S. corruption, for example the channels through which bribes are paid (whether funds flow through lobbying, donations, or more costly inputs) as well as the channels through which politicians punish deviating firms (the threat of taxes or regulation, outright extortion, etc.). 


\section{APPENDIX: VARIABLE DEFINITIONS}

\begin{tabular}{|c|c|}
\hline Variable & Definition \\
\hline $\begin{array}{l}\text { Per Capita Corrup- } \\
\text { tion }\end{array}$ & $\begin{array}{l}\text { Corruption convictions from the DOJ Public Integrity Section scaled by } \\
\text { population scaled by U.S. Census population data }\end{array}$ \\
\hline HHI & $\begin{array}{l}\text { The Herfindahl-Hirschman Index at the } 3 \text {-digit SIC level from Compustat } \\
\text { sales data. }\end{array}$ \\
\hline Acquisitions & Cash outflow related to acquisitions (aqc) scaled by book assets (at) \\
\hline $\begin{array}{l}\text { Capital Expendi- } \\
\text { tures }\end{array}$ & The ratio of capital expenditures to book assets (capx/at) \\
\hline Cash flow & $\begin{array}{l}\text { EBITDA (oibdp) - taxes (txt) - interest(xint) - dividends }(d v c) / \text { book as- } \\
\text { sets }\end{array}$ \\
\hline CF Sigma & $\begin{array}{l}\text { The industry cash flow risk is the standard deviation of cash flow/assets } \\
\text { for ten years prior, where industry is defined by } 2 \text {-digit SIC. }\end{array}$ \\
\hline Dividend & An indicator equal to 1 if the firm pays a dividend. \\
\hline Leverage & (Long-term debt + debt in current liabilities)/book assets \\
\hline Market-to-book & $\begin{array}{l}\text { (Book assets }- \text { common equity }+ \text { common shares outstanding*share price } \\
\text { at fiscal year end)/book assets }\end{array}$ \\
\hline Negative NI & An indicator equal to 1 if a firm had negative net income in a given year \\
\hline Net working capital & Net working capital net of cash scaled by book assets \\
\hline Real Size & Ln(book assets in 2009 dollars) \\
\hline $\mathrm{R} \& \mathrm{D}$ & Research and development expense/sales \\
\hline Segments & The simple count of business segments a firm has \\
\hline Foreign income & The ratio of pre-tax foreign income (pifo) to sales \\
\hline Net debt issuance & Sales of debt (dltis) minus purchases of debt (dltr) \\
\hline Net equity issuance & Sales of equity (sstk) minus purchases of equity (prstkc) \\
\hline Age & Ln(months in CRSP) \\
\hline EBI & EBITDA (oibdp) - taxes (txt) / book assets (at) \\
\hline Equity Mix & Ratio of earned/contributed equity, RE/BE \\
\hline Book equity (BE) & $\begin{array}{l}\text { Total assets }(\text { at })-\text { total liabilities }(\mathrm{tl})+\text { deferred taxes }(\mathrm{txdb})+\text { preferred } \\
\text { stock }(\text { pstkrv })+\text { investment credit }(\text { itcb })+\text { convertible debt }(\text { dvct })\end{array}$ \\
\hline
\end{tabular}


ROA

ROE

$\mathrm{OCF}$

OCF $(\mathrm{SoCF})$

NI

EBITDA

Mod. Altman-Z

$\operatorname{Ln}($ Sales $)$

Investment

Intangibles

DE Incorp

Count State Operations

Concentration

Around HQ

Product Market

Fluidity
Operating income before special items (ib) over total assets (at)

Operating income before special items (ib) over book equity

Operating income before depreciation (oibdp) over total assets (at)

See Denis and McKeon (2012) for definition using statement of cash flows values from Compustat

Net income (ni) over total assets (at)

EBITDA/total assets (at)

$3.3^{*}(\mathrm{EBIT} / \mathrm{at})+1 *($ sale $/$ at $)+1.2^{*}($ current assets $($ act $) /$ at $)+1.4^{*}($ retained earnings (re)/at)

$\operatorname{Ln}($ sale $)$

Capital expenditures (capx) $+\mathrm{R} \& \mathrm{D}(\mathrm{xrd})+$ Acquisitions (aqc)/assets

1 - net property, plant, and equipment (ppent)

Indicator equal to 1 if the firm is incorporated in $\mathrm{DE}$

The simple count of states in which a firm operates (from Garcia and Norli (2012))

The percentage of a firms' operations that are in the state in which it has its headquarters (Garcia and Norli (2012))

A measure of product market threats that come from rival firms (Hoberg et al. (2014)). 


\section{BIBLIOGRAPHY}

Aidt, Toke, 2003. Economic Analysis of Corruption: A Survey. The Economic Journal 113, F-632F652.

Ali, Ashiq, Sandy Klasa, and Eric Yeung, 2009. The limitations of industry concentration measures constructed with Compustat data: implications for finance research. Review of Financial Studies 22, 3839-3871.

Almeida, Heitor, Murillo Campello, and Michael Weisbach, 2004. The Cash Flow Sensitivity of Cash. Journal of Finance 59, 1777-1804.

Amore, Mario Daniele and Morten Bennedsen, 2013. The value of local political connections in a low-corruption environment. Journal of Financial Economics 110, 387-402.

Bates, Thomas, Kathleen Kahle, and René M. Stulz, 2009. Why do firms hold so much more cash than they used to? Journal of Finance 64, 1985-2021.

Baumol, William J., 1952. The transactions demand for cash: An inventory theoretic approach. Quarterly Journal of Economics 66, 545-556.

Borisov, Alex, Nandini Gupta, and Eitan Goldman, 2012. The Value of (Corrupt) Lobbying. Working paper.

Bronars, Stephen, and Donald Deere, 1991. The threat of unionization, the use of debt, and the preservation of shareholder wealth. The Quarterly Journal of Economics 106, 231-254.

Brown, Nerissa, Jared Smith, Roger White, and Chad Zutter, 2013. Greased wheels or just greased palms? Corruption and firm value in the U.S.. Working Paper, Georgia State University.

Butler, Alexander, Larry Fauver, and Sandra Mortal, 2009. Corruption, political connections, and municipal finance. Review of Financial Studies 22, 2873-2905.

Boylan, Richard T., and Cheryl X. Long, 2003. Measuring Public Corruption in the American States: A Survey of State House Reporters. State Politics and Policy Quarterly 3, 420-438. 
Campante, Filipe R. and Quoc-Anh Do, 2010. A Centered Index of Spatial Concentration: Expected Influence Approach and Application to Population and Capital Cities. Harvard Kennedy School WP.

, 2014. Isolated Capital Cities, Accountability and Corruption: Evidence from US States. American Economic Review, forthcoming.

Caprio, Lorenzo, Mara Faccio, and John McConnell, 2013. Sheltering corporate assets from political extraction. Journal of Law, Economics, and Organization 29, 332-354.

Claessens, Stijn, Erik Feijen, and Luc Laeven, 2008. Political connections and preferential access to finance: The role of campaign contributions. Journal of Financial Economics 88, 554-580.

Cohen, Lauren, Joshua Coval, and Christopher Malloy, 2011. Do Powerful Politicians Cause Corporate Downsizing? Journal of Political Economy 119, 1015-1060.

Daines, R., 2001. Does Delaware law improve firm value? Journal of Financial Economics 62, 525558.

Denis, David J., and Valeriy Sibilkov, 2010. Financial Constraints, Investment, and the Value of Cash Holdings. Review of Financial Studies 23, 247-269.

Denis, David J., and Stephen McKeon, 2012. Debt Financing and Financial Flexibility Evidence from Proactive Leverage Increases. Review of Financial Studies 25, 1897-1929.

Dittmar, Amy, and Jan Mahrt-Smith, 2007. Corporate governance and the value of cash holdings. Journal of Financial Economics 83, 599-634.

Duchin, Ran, 2010. Cash Holdings and Corporate Diversification. Journal of Finance 65, 955-992.

Durnev, Art, and Larry Fauver, 2010. Stealing from thieves: firm governance and performance when states are predatory. Working paper, University of Tennessee.

Faccio, Mara, Ronald Masulis, and John McConnell, 2006. Political Connections and Corporate Bailouts. The Journal of Finance 61, 2597-2635.

Faulkender, Michael, and Rong Wang, 2006. Corporate Financial Policy and the Value of Cash. Journal of Finance 61, 1957-1990.

Fan, Joseph P. H., Sheridan Titman, and Garry Twite, 2012. An International Comparison of Capital Structure and Debt Maturity Choices. Journal of Financial and Quantitative Analysis 47, 23-56. 
Fisman, Raymond, and Roberta Gatti, 2002. Decentralization and corruption: Evidence from U.S. Federal Transfer Programs. Public Choice 113, 25-35.

Foley, Fritz, Jay Hartzell, Sheridan Titman, and Garry Twite, 2007. Why do firms hold so much cash? A tax-based explanation. Journal of Financial Economics 86, 579-607.

Gao, Huasheng, Jarrad Harford, and Kai Li, 2013. Determinants of corporate cash policy: Insights from private firms. Journal of Financial Economics, forthcoming.

García, Diego and Øyvind Norli, 2012. Geographic dispersion and stock returns. Journal of Financial Economics 106, 547-565.

Garner, Jacqueline L., Ted Kim, and Adam S. Yore, 2012. Corrupting Innovation. Working paper.

Glaeser, Edward, and Raven Saks, 2006. Corruption in America. Journal of Public Economics 90, 1053-1072.

Goldman, Eitan, Jorg Rocholl, and Jongil So, 2009. Do Politically Connected Boards Affect Firm Value? Review of Financial Studies 22, 2331-2360.

Gormley, Todd, and David Matsa, 2014. Common Errors: How to (and Not to) Control for Unobserved Heterogeneity. Review of Financial Studies 27, 617-661.

Graham, John and Michael Leary, 2011. A Review of Empirical Capital Structure Research and Directions for the Future. Annual Review of Financial Economics 3, 309-345.

Harford, Jarrad, Sattar A. Mansi, and William F. Maxwell, 2008. Corporate governance and firm cash holdings in the US. Journal of Financial Economics 87, 535-555.

Haushalter, David, Sandy Klasa, and William F. Maxwell, 2007. The influence of product market dynamics on a firm's cash holdings and hedging behavior. Journal of Financial Economics 84, 797-825.

Hirsch, Barry and David Macpherson, 2003. Union Membership and Coverage Database from the Current Population Survey: Note. Industrial and Labor Relations Review 56, 349-354.

Hoberg, Gerard and Gordon Phillips, 2010a. Dynamic Product-Based Industry Classifications and Endogenous Product Differentiation. Working Paper, University of Maryland. 
2010b. Product Market Synergies and Competition in Mergers and Acquisitions: A Text-Based Analysis. Review of Financial Studies 23, 3773-3811.

Hoberg, Gerard, Gordon Phillips, and Nagpurnanand Prabhala, 2014. Product Market Threats, Payouts, and Financial Flexibility. Journal of Finance 69, 293-324.

Jain, Arvind, 2001. Corruption: A Review. Journal of Economic Surveys 15, 71-121.

Jensen, Michael, 1986. Agency costs of free cash flow, corporate finance, and takeovers. American Economic Review 76, 323-329.

Keynes, John M., 1936. The General Theory of Employment, Interest, and Money. London: Palgrave Macmillan.

Kim, Chang-Soo, David C. Mauer, and Ann E. Sherman, 1998. The Determinants of Corporate Liquidity: Theory and Evidence. Journal of Financial and Quantitative Analysis 33, 335-359.

Klasa, Sandy, William F. Maxwell, and Hernán Ortiz-Molina, 2009. The strategic use of corporate cash holdings in collective bargaining with labor unions. Journal of Financial Economics $92,421-442$.

Kleibergen, F. and Paap, R. 2006. Generalized Reduced Rank Tests Using the Singular Value Decomposition. Journal of Econometrics, Vol. 133, pp. 97-126.

Kulchania, Manoj, and Shawn Thomas, 2013. The substitution of financial flexibility for operational flexibility: cash vs. inventory. Working paper.

Lins, Karl V., Henri Servaes, and Peter Tufano, 2010. What drives corporate liquidity? An international survey of cash holdings and lines of credit. Journal of Financial Economics 98, 160176.

Matsa, David A., 2010. Capital Structure as a Strategic Variable: Evidence from Collective Bargaining. Journal of Finance 65, 1197-1232.

Mauro, Paolo, 1995. Corruption and growth. Quarterly Journal of Economics 110, 681-713.

McChesney, Fred S., 1987. Rent Extraction and Rent Creation in the Economic Theory of Regulation. Journal of Legal Studies 16, 101-118.

Mikkelson, Wayne H., and M. Megan Partch, 2003. Do persistent large cash reserves hinder performance? Journal of Quantitative and Financial Analysis 38, 275-294. 
Miller, Merton and Daniel Orr, 1962. A Model of the Demand for Money by Firms. Quarterly Journal of Economics 80, 413-435.

Modigliani, Franco, and Merton Miller, 1958. The Cost of Capital, Corporate Finance and the Theory of Investment. American Economic Review 48, 261-297.

Murphy, Kevin M., Andrei Shleifer, Robert Vishny, 1993. Why is Rent-Seeking so Costly to Growth? The American Economic Review 83, 409-414.

Myers, Stewart, and Raghuram Rajan, 1998. The paradox of liquidity. Quarterly Journal of Economics 113, 733-771.

Newey, Whitney K., and Kenneth D.West, 1987, A simple positive semi-definite heteroskedasticity and autocorrelation consistent covariance matrix, Econometrica 55, 703-708.

Opler, Tim, Lee Pinkowitz, René M. Stulz, and Rohan Williamson, 1999. The determinants and implications of corporate cash holdings. Journal of Financial Economics 52, 3-46.

Perotti, Enrico, and Kathryn Spier, 1993. Capital structure as a bargaining tool: the role of leverage in contract renegotiation. American Economic Review 83, 1131-1141.

Petersen, Mitchell, 2009. Estimating Standard Errors in Finance Panel Data Sets: Comparing Approaches. Review of Financial Studies 22, 435-480.

Rose-Ackerman, Susan, 1975. The economics of corruption. Journal of Public Economics 4, 187203.

Shleifer, Andrei, and Robert Vishny, 1993. Corruption. Quarterly Journal of Economics 108, 599617.

$995-1025$.

, 1994. Politicians and firms. Quarterly Journal of Economics 109,

Stock, J.H., Yogo, M., 2005. Testing for weak instruments in linear IV regression. In: Stock, J.H., Andrews, D.W.K., (Eds.), Identification and Inference for Econometric Models: A Festschrift in Honor of Thomas Rothenberg. Cambridge University Press, Cambridge, pp. 80-108. (Ch. $5)$.

Stulz, René M., 2005. The limits of financial globalization. Journal of Finance 60, 1595-1638. 
Svensson, Jakob, 2003. Who Must Pay Bribes and How Much? Evidence from a Cross Section of Firms. Quarterly Journal of Economics 118, 207-230.

Wei, Shang-Jin, 2000. How Taxing is Corruption on International Investors? The Review of Economics and Statistics 82, 1-11.

Yun, Hayong, 2009. The choice of corporate liquidity and corporate governance. Review of Financial Studies 22, 1447-1475. 
1985

"Also in Providence, Rhode Island, the Director of Public Property for the City of Providence, Joseph C. DiSanto, and the Chairman of the Providence Water Supply Board, Richard A. Carroll, were charged with extortion of kickback payments from a supplier of plumbing services to the City. These charges were the result of a joint effort by the Public Integrity Section and the Providence Organized Crime and Racketeering Field Office. DiSanto and Carroll were convicted after a trial of the charges, but the trial court later granted the defendants' motion for a new trial. Efforts to reinstate the convictions are ongoing." [pg. 21]

$\underline{1998}$

\section{United States v. Johnson, Northern District of Ohio}

"Ohio State Senator Jeffrey D. Johnson was convicted on November 20, 1998, by a federal jury of three counts of extortion. The jury acquitted Johnson on a fourth extortion count. Johnson had been indicted on March 4, 1998, on these charges. The charges resulted from an FBI investigation which made use of a cooperating witness to record conversations with Johnson.

"Johnson demanded personal "loans" and campaign contributions from Cleveland-area grocery store owners, in exchange for which Johnson helped the store owners obtain various state and county licenses. Johnson was paid a total of $\$ 7,000$ in purported "loans" and $\$ 10,000$ in campaign contributions. Johnson was convicted of accepting money for his official acts on behalf of the store owners' efforts to obtain state contracts and permits regarding the Federal Women, Infants and Children Program, the sale of beer and wine, and the sale of lottery tickets.

"The judge denied post-trial defense motions for a new trial and for a judgment of acquittal notwithstanding the verdict, in which Johnson contended, among other things, that he had been unlawfully entrapped. Johnson has since been sentenced to 15 months' imprisonment, one year of supervised release, and 250 hours of community service." [pg. 29]

2007

\section{United States v. Kohring}

"Victor H. Kohring, who served in the Alaska State House of Representatives from 1994 to 2007, was found guilty on November 1, 2007, of conspiracy, bribery, and attempted extortion. On May 4, 2007, Kohring was arrested following the unsealing of an indictment charging him, Kott, Allen, and Smith with various public corruption offenses. While serving as a representative, Kohring solicited bribes from and took action to benefit the financial interests of VECO Corporation. Kohring repeatedly agreed to lobby his colleagues and, if needed, cast votes in VECO's favor on a key petroleum production tax proposal pending before the Alaska legislature. In exchange, Kohring received multiple cash payments and solicited a $\$ 17,000$ payment." [pg. 41]

\section{Figure 1: Case Summaries}

The figure shows some excerpts from various years of the annual "Report to Congress on the Activities and Operations of the Public Integrity Section." While not all cases are described in this detail, all reports contain a handful of large or noteworthy cases. Though clearly not all cases will be extortion or bribery based, the subset displayed was selected because of its applicability to the analysis at hand. 


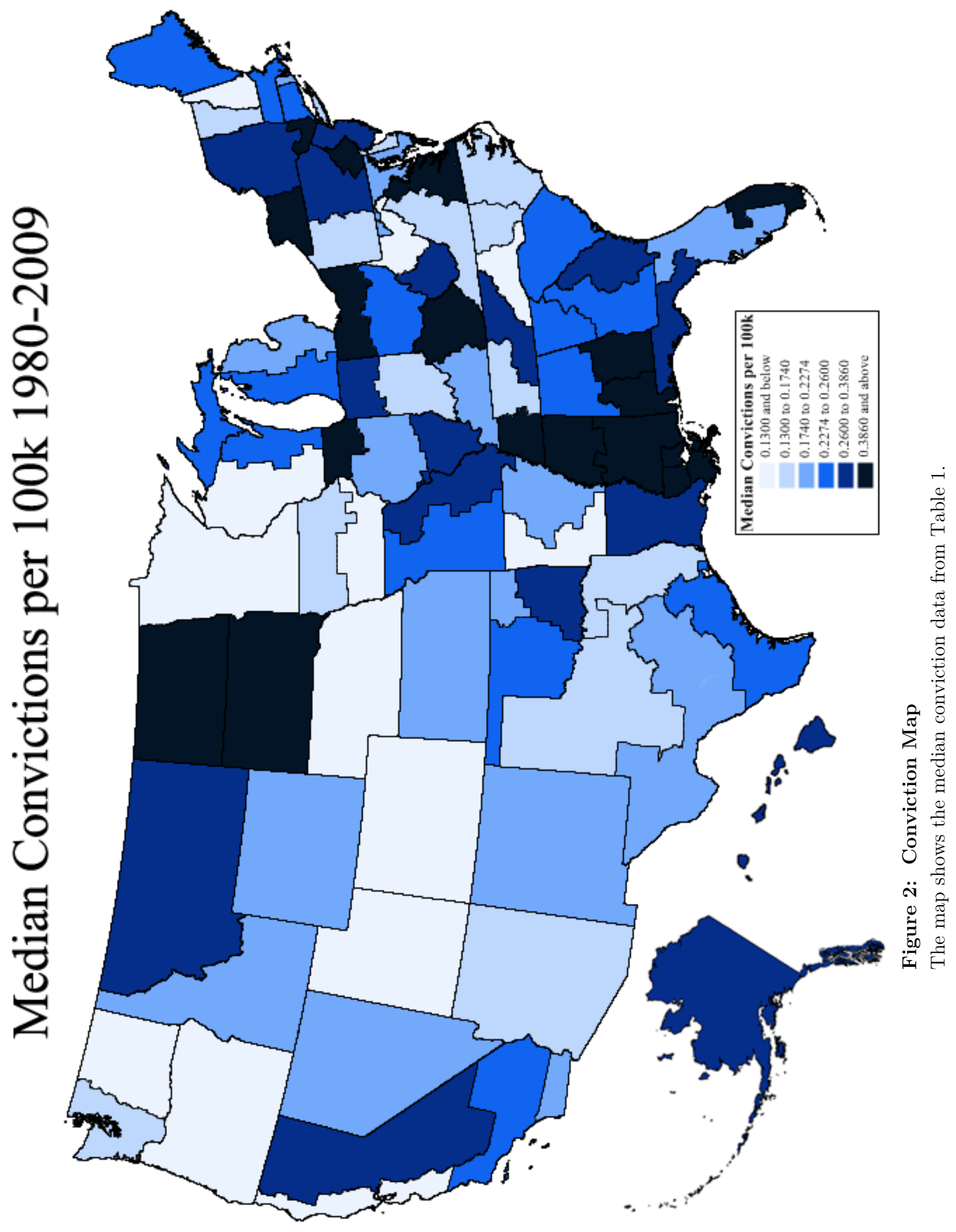


Table 1

\section{Summary Statistics for Convictions per 100,000, by district}

This table provides the summary statistics for the number of corruption convictions per hundred thousand, for each U.S. district court district. All 90 judicial districts from the 50 U.S. states and Washington D.C. are included in the sample. These data are for the thirty years 1980-2009 and are for all firm-years with location data. Therefore, all future tables contain a subset of these data, as the accounting data requirements are more onerous. Conviction data come from the U.S. Department of Justice Public Integrity Section. Data are ordered by median convictions per hundred thousand.

\begin{tabular}{|c|c|c|c|c|c|c|}
\hline \multirow{2}{*}{$\begin{array}{c}\text { U.S. District Court } \\
\text { District }\end{array}$} & \multirow{2}{*}{$\begin{array}{c}\text { Firm-years in } \\
\text { District }\end{array}$} & \multicolumn{5}{|c|}{ Standard } \\
\hline & & Median & Mean & Deviation & Minimum & Maximum \\
\hline Washington D.C. & 681 & 5.368 & 6.252 & 3.433 & 2.041 & 14.160 \\
\hline Tennessee - Western & 741 & 1.239 & 1.638 & 1.651 & 0.433 & 9.816 \\
\hline Louisiana - Eastern & 640 & 1.059 & 0.991 & 0.560 & 0.122 & 2.223 \\
\hline Florida - Southern & 6,079 & 0.965 & 1.152 & 0.844 & 0.000 & 3.341 \\
\hline Mississippi - Northern & 144 & 0.838 & 0.968 & 0.838 & 0.000 & 4.053 \\
\hline North Dakota & 134 & 0.623 & 0.720 & 0.587 & 0.000 & 2.528 \\
\hline Alabama - Southern & 163 & 0.614 & 0.685 & 0.569 & 0.000 & 2.215 \\
\hline Louisiana - Middle & 238 & 0.598 & 0.695 & 0.547 & 0.000 & 2.244 \\
\hline Illinois - Northern & 8,369 & 0.555 & 0.591 & 0.311 & 0.203 & 1.493 \\
\hline New York - Southern & 9,042 & 0.554 & 0.539 & 0.419 & 0.000 & 1.493 \\
\hline Mississippi - Southern & 617 & 0.532 & 0.562 & 0.357 & 0.000 & 1.297 \\
\hline Pennsylvania - Eastern & 5,590 & 0.492 & 0.523 & 0.253 & 0.082 & 1.069 \\
\hline Kentucky - Eastern & 538 & 0.477 & 0.603 & 0.385 & 0.000 & 1.546 \\
\hline South Dakota & 230 & 0.430 & 0.602 & 0.520 & 0.000 & 2.011 \\
\hline Ohio - Northern & 3,922 & 0.426 & 0.446 & 0.281 & 0.034 & 1.535 \\
\hline Alabama - Middle & 142 & 0.412 & 0.504 & 0.360 & 0.000 & 2.410 \\
\hline Virginia - Eastern & 4,435 & 0.395 & 0.489 & 0.337 & 0.000 & 1.311 \\
\hline New York - Western & 5,714 & 0.388 & 0.693 & 0.792 & 0.072 & 3.837 \\
\hline Pennsylvania - Middle & 931 & 0.382 & 0.389 & 0.184 & 0.135 & 0.891 \\
\hline Oklahoma - Eastern & 48 & 0.361 & 0.546 & 0.622 & 0.000 & 2.123 \\
\hline Florida - Northern & 194 & 0.354 & 0.449 & 0.309 & 0.000 & 1.571 \\
\hline Montana & 212 & 0.351 & 0.471 & 0.529 & 0.000 & 2.127 \\
\hline New York - Northern & 1,204 & 0.340 & 0.502 & 0.447 & 0.059 & 2.479 \\
\hline Alaska & 95 & 0.333 & 0.608 & 0.696 & 0.000 & 2.552 \\
\hline New Jersey & 10,850 & 0.328 & 0.339 & 0.172 & 0.079 & 0.718 \\
\hline Illinois - Southern & 58 & 0.317 & 0.406 & 0.460 & 0.000 & 1.893 \\
\hline
\end{tabular}


Table 1-- Continued

\begin{tabular}{|c|c|c|c|c|c|c|}
\hline $\begin{array}{c}\text { U.S. District Court } \\
\text { District }\end{array}$ & $\begin{array}{c}\text { Firm-years in } \\
\text { District }\end{array}$ & Median & Mean & $\begin{array}{l}\text { Standard } \\
\text { Deviation }\end{array}$ & Minimum & Maximum \\
\hline Hawaii & 424 & 0.302 & 0.323 & 0.254 & 0.000 & 1.118 \\
\hline California - Eastern & 962 & 0.300 & 0.324 & 0.151 & 0.000 & 0.627 \\
\hline West Virginia - Southerr & 187 & 0.300 & 0.470 & 0.363 & 0.000 & 1.420 \\
\hline Indiana - Northern & 1,047 & 0.297 & 0.304 & 0.166 & 0.000 & 0.705 \\
\hline Tennessee - Eastern & 711 & 0.296 & 0.331 & 0.223 & 0.000 & 1.300 \\
\hline Louisiana - Western & 374 & 0.292 & 0.315 & 0.182 & 0.000 & 0.665 \\
\hline Georgia - Southern & 216 & 0.280 & 0.481 & 0.633 & 0.000 & 2.966 \\
\hline Florida - Middle & 4,488 & 0.268 & 0.239 & 0.125 & 0.039 & 0.581 \\
\hline Missouri - Eastern & 2,188 & 0.261 & 0.319 & 0.216 & 0.038 & 0.758 \\
\hline Texas - Southern & 5,362 & 0.258 & 0.280 & 0.179 & 0.000 & 0.778 \\
\hline Georgia - Middle & 386 & 0.255 & 0.357 & 0.285 & 0.000 & 1.173 \\
\hline Ohio - Southern & 3,806 & 0.253 & 0.298 & 0.154 & 0.000 & 0.577 \\
\hline Georgia - Northern & 4,830 & 0.252 & 0.332 & 0.194 & 0.067 & 0.922 \\
\hline Massachusetts & 9,857 & 0.249 & 0.288 & 0.175 & 0.017 & 0.819 \\
\hline Missouri - Western & 1,195 & 0.248 & 0.262 & 0.169 & 0.000 & 0.672 \\
\hline Michigan - Western & 1,057 & 0.246 & 0.216 & 0.134 & 0.000 & 0.440 \\
\hline Maine & 306 & 0.244 & 0.260 & 0.221 & 0.000 & 0.808 \\
\hline Wisconsin - Eastern & 2,191 & 0.239 & 0.240 & 0.121 & 0.033 & 0.545 \\
\hline California - Central & 14,291 & 0.238 & 0.266 & 0.146 & 0.015 & 0.592 \\
\hline Connecticut & 5,546 & 0.235 & 0.256 & 0.144 & 0.000 & 0.690 \\
\hline South Carolina & 1,275 & 0.231 & 0.321 & 0.239 & 0.000 & 0.868 \\
\hline Oklahoma - Western & 985 & 0.228 & 0.641 & 0.890 & 0.000 & 3.095 \\
\hline Alabama - Northern & 969 & 0.228 & 0.343 & 0.315 & 0.000 & 1.430 \\
\hline Oklahoma - Northern & 972 & 0.225 & 0.283 & 0.306 & 0.000 & 1.191 \\
\hline California - Southern & 4,608 & 0.225 & 0.248 & 0.172 & 0.000 & 0.989 \\
\hline Maryland & 3,861 & 0.218 & 0.274 & 0.199 & 0.000 & 0.689 \\
\hline Arkansas - Eastern & 351 & 0.216 & 0.264 & 0.267 & 0.000 & 1.174 \\
\hline Kentucky - Western & 800 & 0.214 & 0.242 & 0.194 & 0.000 & 0.885 \\
\hline New Mexico & 472 & 0.209 & 0.234 & 0.159 & 0.000 & 0.574 \\
\hline Texas - Western & 2,902 & 0.204 & 0.231 & 0.127 & 0.000 & 0.551 \\
\hline Nevada & 2,184 & 0.204 & 0.197 & 0.192 & 0.000 & 0.946 \\
\hline Idaho & 512 & 0.202 & 0.215 & 0.184 & 0.000 & 0.606 \\
\hline
\end{tabular}


Table 1-- Continued

\begin{tabular}{|c|c|c|c|c|c|c|}
\hline $\begin{array}{c}\text { U.S. District Court } \\
\text { District }\end{array}$ & $\begin{array}{c}\text { Firm-years in } \\
\text { District }\end{array}$ & Median & Mean & $\begin{array}{l}\text { Standard } \\
\text { Deviation }\end{array}$ & Minimum & Maximum \\
\hline Rhode Island & 653 & 0.200 & 0.269 & 0.228 & 0.000 & 0.832 \\
\hline Wyoming & 231 & 0.199 & 0.259 & 0.338 & 0.000 & 1.580 \\
\hline Kansas & 1,358 & 0.183 & 0.184 & 0.132 & 0.000 & 0.428 \\
\hline Illinois - Central & 624 & 0.183 & 0.234 & 0.209 & 0.000 & 1.074 \\
\hline Michigan - Eastern & 3,167 & 0.176 & 0.208 & 0.134 & 0.015 & 0.691 \\
\hline North Carolina - Middle & 1,785 & 0.173 & 0.206 & 0.164 & 0.000 & 0.819 \\
\hline North Carolina - Easterr. & 1,018 & 0.171 & 0.220 & 0.182 & 0.000 & 0.614 \\
\hline Delaware & 855 & 0.167 & 0.323 & 0.332 & 0.000 & 1.144 \\
\hline Texas - Eastern & 1,327 & 0.163 & 0.274 & 0.272 & 0.000 & 1.223 \\
\hline Tennessee - Middle & 1,255 & 0.161 & 0.183 & 0.193 & 0.000 & 0.994 \\
\hline Vermont & 217 & 0.161 & 0.146 & 0.176 & 0.000 & 0.805 \\
\hline Texas - Northern & 10,294 & 0.160 & 0.195 & 0.151 & 0.000 & 0.611 \\
\hline Arizona & 2,829 & 0.156 & 0.217 & 0.184 & 0.000 & 0.803 \\
\hline Iowa - Northern & 543 & 0.154 & 0.151 & 0.131 & 0.000 & 0.468 \\
\hline New York - Eastern & 5,199 & 0.151 & 0.196 & 0.197 & 0.000 & 0.853 \\
\hline Pennsylvania - Western & 2,260 & 0.147 & 0.164 & 0.083 & 0.025 & 0.404 \\
\hline Virginia - Western & 775 & 0.141 & 0.208 & 0.202 & 0.000 & 0.742 \\
\hline Washington - Western & 2,909 & 0.137 & 0.139 & 0.116 & 0.000 & 0.405 \\
\hline Indiana - Southern & 1,925 & 0.133 & 0.162 & 0.114 & 0.000 & 0.527 \\
\hline North Carolina - Wester & 1,111 & 0.129 & 0.185 & 0.159 & 0.000 & 0.580 \\
\hline Minnesota & 5,614 & 0.110 & 0.134 & 0.101 & 0.000 & 0.484 \\
\hline Utah & 1,984 & 0.108 & 0.144 & 0.131 & 0.000 & 0.426 \\
\hline California - Northern & 12,770 & 0.103 & 0.142 & 0.123 & 0.000 & 0.633 \\
\hline Arkansas - Western & 430 & 0.093 & 0.142 & 0.165 & 0.000 & 0.636 \\
\hline New Hampshire & 820 & 0.089 & 0.128 & 0.155 & 0.000 & 0.739 \\
\hline Colorado & 6,442 & 0.084 & 0.159 & 0.160 & 0.000 & 0.496 \\
\hline Oregon & 1,770 & 0.079 & 0.089 & 0.083 & 0.000 & 0.300 \\
\hline Washington - Eastern & 357 & 0.077 & 0.108 & 0.133 & 0.000 & 0.459 \\
\hline Iowa - Southern & 745 & 0.066 & 0.142 & 0.161 & 0.000 & 0.537 \\
\hline Nebraska & 675 & 0.062 & 0.139 & 0.152 & 0.000 & 0.573 \\
\hline Wisconsin - Western & 613 & 0.048 & 0.079 & 0.092 & 0.000 & 0.317 \\
\hline West Virginia - Northerı & 221 & 0.000 & 0.102 & 0.129 & 0.000 & 0.379 \\
\hline
\end{tabular}


Table 2

\section{Summary Statistics}

The sample includes all Compustat firm-years from 1980-2009 that include: headquarter location data, positive book value of assets and sales data, and accounting data. Further missing data requirements on the many control variables also trim the sample size. Financial firms (SIC 6000-6999) and utilities (SIC 49004999) are excluded from the sample, which leaves an unbalanced panel of 117,410 firm-years for 14,044 firms. Variable definitions are provided in the Appendix.

\begin{tabular}{|c|c|c|c|c|c|c|}
\hline & \multirow[b]{2}{*}{$\mathrm{N}$} & \multicolumn{5}{|c|}{ Standard } \\
\hline & & Mean & Median & Deviation & Minimum & Maximum \\
\hline Cash ratio & 117,410 & 0.168 & 0.078 & 0.210 & 1 & 0.000 \\
\hline Log cash/net assets & 116,133 & -2.450 & -2.442 & 1.919 & 7.022 & -13.020 \\
\hline Convictions per 100,000 & 117,410 & 0.326 & 0.236 & 0.349 & 2 & 0.000 \\
\hline HHI & 117,410 & 0.165 & 0.122 & 0.139 & 1.000 & 0.028 \\
\hline Market-to-book & 117,410 & 2.447 & 1.435 & 3.934 & 39.625 & 0.541 \\
\hline Leverage & 117,410 & 0.285 & 0.215 & 0.361 & 3 & 0.000 \\
\hline Cash flow & 117,410 & -0.090 & 0.053 & 0.599 & 0.293 & -5.568 \\
\hline Net working capital & 117,410 & 0.011 & 0.081 & 0.635 & 0.569 & -6.372 \\
\hline Capital expenditures & 117,410 & 0.069 & 0.044 & 0.078 & 0 & 0.000 \\
\hline Real Size & 117,410 & 4.708 & 4.642 & 2.234 & 10.808 & -1.666 \\
\hline Dividend Dummy & 117,410 & 0.280 & 0 & 0.449 & 1 & 0.000 \\
\hline Dividends & 117,410 & 0.007 & 0 & 0.019 & 0 & 0.000 \\
\hline Negative NI Dummy & 117,410 & 0.394 & 0 & 0.489 & 1 & 0.000 \\
\hline $\mathrm{R} \& \mathrm{D}$ & 117,410 & 0.200 & 0 & 0.901 & 7 & 0.000 \\
\hline Acquisitions & 117,410 & 0.020 & 0 & 0.059 & 0.355 & -0.005 \\
\hline CF Sigma & 117,410 & 0.516 & 0.151 & 1.016 & 6.960 & 0.017 \\
\hline Segments & 117,410 & 1.541 & 1.000 & 1.188 & 16.000 & 1.000 \\
\hline Ln(Sales) & 112,864 & -0.270 & 0.278 & 7.079 & 36.941 & -41.476 \\
\hline Modified Altman Z & 117,410 & -0.076 & 1.994 & 10.419 & 6.079 & -100.019 \\
\hline EBITDA & 117,410 & -0.021 & 0.101 & 0.518 & 0.454 & -4.391 \\
\hline Intangibles & 117,410 & 0.708 & 0.767 & 0.230 & 1.000 & -0.667 \\
\hline Age & 98,976 & 5.168 & 5.263 & 0.868 & 6.928 & 0.000 \\
\hline DE Incorporation & 112,516 & 0.568 & 1.000 & 0.495 & 1 & 0.000 \\
\hline
\end{tabular}


Table 3

\section{Univariate Analysis by Corrupt and Non-corrupt Districts}

The sample includes all Compustat firm-years 1980-2009 that include: headquarter location data, positive book value of assets and sales, and cash flow data. Financial firms (SIC 6000-6999) and utilities (SIC 49004999) are excluded from the sample, which leaves a panel of 117,410 firm-years for 14,044 unique firms. The unit of observation in the table is the firm, in which the firm's sample median value is the value used. Panel A examines univariate statistics for the full sample of firms. Panel B reports these statistics for firms matched on size and industry, but which differ on the corruption regime they face. Corrupt is a long-run indicator that assigns a district court district as corrupt if its median per capita corruption is above the sample median. This is done by taking the time series median for the 30 sample years of per capita convictions for each district and then those above the cross-sectional median of the district medians are classified as corrupt districts. The final columns contain the t-value from the t-test of sample means [Wilcoxon ranksum test]. ${ }^{* * *},{ }^{* *}$, and ${ }^{*}$ denote significance at the $.01, .05$, and .1 levels, respectively. Variable definitions are provided in the Appendix.

\begin{tabular}{|c|c|c|c|c|c|c|}
\hline & \multicolumn{2}{|c|}{ Non-corrupt } & \multicolumn{2}{|c|}{ Corrupt } & \multirow{2}{*}{\multicolumn{2}{|c|}{$\begin{array}{c}\text { T-value difference in Means } \\
\text { [Rank-sum test }]\end{array}$}} \\
\hline & \multicolumn{2}{|c|}{ Mean [Median] } & \multicolumn{2}{|c|}{ Mean [Median] } & & \\
\hline \multicolumn{7}{|c|}{ Panel A: Full Sample } \\
\hline Cash ratio & 0.235 & {$[0.140]$} & 0.148 & {$[0.070]$} & $15.967 * * *$ & {$[15.411] * * *$} \\
\hline Log cash/net assets & -1.822 & {$[-1.789]$} & -2.503 & {$[-2.567]$} & $15.136 * * *$ & {$[15.628]^{* * *}$} \\
\hline Leverage & 0.396 & {$[0.169]$} & 0.332 & {$[0.244]$} & 0.427 & {$[-10.855]^{* * *}$} \\
\hline Market-to-book & 3.612 & {$[1.693]$} & 7.187 & {$[1.423]$} & -1.324 & {$[9.339] * * *$} \\
\hline \multicolumn{7}{|c|}{ Panel B: Firms matched on size and 3-digit SIC } \\
\hline Cash ratio & 0.202 & {$[0.108]$} & 0.161 & {$[0.078]$} & $6.635^{* * *}$ & {$[6.058] * * *$} \\
\hline Log cash/net assets & -2.078 & {$[-2.089]$} & -2.397 & {$[-2.455]$} & $5.888^{* * *}$ & {$[6.317] * * *$} \\
\hline Leverage & 0.265 & {$[0.208]$} & 0.294 & {$[0.234]$} & $-2.349 * *$ & {$[-3.569] * * *$} \\
\hline Market-to-book & 2.427 & {$[1.556]$} & 2.560 & {$[1.466]$} & -0.907 & {$[2.156] * *$} \\
\hline
\end{tabular}


Table 4

\section{Panel Regressions of Cash Holdings on Corruption}

The sample includes all Compustat firm-years 1980-2009 that include: headquarter location data, positive book value of assets and sales, and accounting data. Financial firms (SIC 6000-6999) and utilities (SIC 4900-4999) are excluded from the main sample, which leaves an unbalanced panel of 117,410 firm-years for 14,044 unique firms. The dependent variable is the cash ratio. Industry fixed effects are dummies for twodigit SIC code. Models (5) and (6) use the state corruption ranking from the State Integrity Investigation, which is explained further in the text. Standard errors are in parentheses below each coefficient estimate. Standard errors are all heteroscedasticity robust Rogers standard errors clustered by both firm and time. The Fama-MacBeth model uses Newey-West (1987) standard errors to control for autocorrelation. ***, **, and $*$ denote significance at the .01, .05, and .1 levels, respectively. Variable definitions are provided in the Appendix.

(1)

(2)

(3)

(4)

(5)

(6)

Pooled Pooled Pooled Fama- Pooled Pooled

\begin{tabular}{lcccc} 
Model & OLS & OLS & OLS & MacBeth \\
\hline Convictions per 100,000 & $-0.017^{* * *}$ & $-0.017^{* * *}$ & $-0.021^{* * *}$ & $-0.019^{* *}$ \\
& $(0.003)$ & $(0.003)$ & $(0.005)$ & $(0.007)$
\end{tabular}

Survey Corruption

\begin{tabular}{lcccccc} 
Survey Corruption & & & & & $-0.003^{* * *}$ & $-0.002^{* * *}$ \\
& & & & $(0.000)$ & $(0.000)$ \\
HHI & $-0.096^{* * *}$ & $-0.071^{* * *}$ & $-0.073^{* * *}$ & $-0.091^{* * *}$ & $-0.155^{* * *}$ & $-0.088^{* * *}$ \\
& $(0.014)$ & $(0.009)$ & $(0.012)$ & $(0.026)$ & $(0.012)$ & $(0.013)$ \\
Market-to-book & $0.008^{* * *}$ & $0.007^{* * *}$ & $0.014^{* * *}$ & $0.008^{* * *}$ & $0.007^{* * *}$ & $0.006^{* * *}$ \\
& $(0.001)$ & $(0.001)$ & $(0.002)$ & $(0.000)$ & $(0.001)$ & $(0.001)$ \\
Leverage & $-0.235^{* * *}$ & $-0.221^{* * *}$ & $-0.246^{* * *}$ & $-0.244^{* * *}$ & $-0.177^{* * *}$ & $-0.163^{* * *}$ \\
& $(0.011)$ & $(0.012)$ & $(0.013)$ & $(0.022)$ & $(0.008)$ & $(0.008)$ \\
Cash Flow & $0.038^{* * *}$ & $0.035^{* * *}$ & $0.085^{* * *}$ & $0.037^{* * *}$ & $0.029^{* * *}$ & $0.029^{* * *}$ \\
& $(0.004)$ & $(0.003)$ & $(0.019)$ & $(0.002)$ & $(0.004)$ & $(0.004)$ \\
Net Working Capital & $-0.077^{* * *}$ & $-0.070^{* * *}$ & $-0.133^{* * *}$ & $-0.097^{* * *}$ & $-0.046^{* * *}$ & $-0.042^{* * *}$ \\
& $(0.008)$ & $(0.007)$ & $(0.018)$ & $(0.018)$ & $(0.005)$ & $(0.004)$ \\
Capital Expenditures & $-0.288^{* * *}$ & $-0.256^{* * *}$ & $-0.431^{* * *}$ & $-0.324^{* * *}$ & $-0.386^{* * *}$ & $-0.316^{* * *}$ \\
& $(0.021)$ & $(0.016)$ & $(0.037)$ & $(0.039)$ & $(0.042)$ & $(0.043)$ \\
Real Size & $-0.006^{* * *}$ & $-0.006^{* * *}$ & $-0.007^{* * *}$ & $-0.007^{* * *}$ & $-0.004^{* * *}$ & $-0.003^{* *}$ \\
& $(0.001)$ & $(0.001)$ & $(0.001)$ & $(0.001)$ & $(0.001)$ & $(0.001)$ \\
R\&D & $0.070^{* * *}$ & $0.064^{* * *}$ & $0.089^{* * *}$ & $0.067^{* * *}$ & $0.061^{* * *}$ & $0.054^{* * *}$ \\
& $(0.002)$ & $(0.002)$ & $(0.011)$ & $(0.002)$ & $(0.002)$ & $(0.002)$ \\
\hline & & & & & continued
\end{tabular}


Table 4--Continued

\begin{tabular}{|c|c|c|c|c|c|c|}
\hline Model & $\begin{array}{c}(1) \\
\text { Pooled } \\
\text { OLS }\end{array}$ & $\begin{array}{c}(2) \\
\text { Pooled } \\
\text { OLS }\end{array}$ & $\begin{array}{c}(3) \\
\text { Pooled } \\
\text { OLS }\end{array}$ & $\begin{array}{c}(4) \\
\text { Fama- } \\
\text { MacBeth }\end{array}$ & $\begin{array}{c}(5) \\
\text { Pooled } \\
\text { OLS }\end{array}$ & $\begin{array}{c}(6) \\
\text { Pooled } \\
\text { OLS }\end{array}$ \\
\hline Acquisitions & $\begin{array}{c}-0.213^{* * *} \\
(0.020)\end{array}$ & $\begin{array}{c}-0.244^{* * *} \\
(0.020)\end{array}$ & $\begin{array}{c}-0.332^{* * *} \\
(0.027)\end{array}$ & $\begin{array}{c}-0.208^{* * *} \\
(0.043)\end{array}$ & $\begin{array}{c}-0.306^{* * *} \\
(0.024)\end{array}$ & $\begin{array}{c}-0.344^{* * *} \\
(0.023)\end{array}$ \\
\hline CF Sigma & $\begin{array}{c}0.016^{* * *} \\
(0.001)\end{array}$ & $\begin{array}{c}0.002 \\
(0.002)\end{array}$ & $\begin{array}{l}0.003^{*} \\
(0.002)\end{array}$ & $\begin{array}{c}0.083^{* * *} \\
(0.022)\end{array}$ & $\begin{array}{c}0.012^{* * *} \\
(0.001)\end{array}$ & $\begin{array}{c}-0.002^{* * *} \\
(0.001)\end{array}$ \\
\hline Dividend & $\begin{array}{c}-0.042^{* * *} \\
(0.003)\end{array}$ & $\begin{array}{c}-0.035^{* * *} \\
(0.003)\end{array}$ & $\begin{array}{c}-0.040^{* * *} \\
(0.004)\end{array}$ & $\begin{array}{c}-0.039^{* * *} \\
(0.004)\end{array}$ & $\begin{array}{c}-0.045^{* * *} \\
(0.005)\end{array}$ & $\begin{array}{c}-0.035^{* * *} \\
(0.005)\end{array}$ \\
\hline Segments & $\begin{array}{c}-0.009^{* * *} \\
(0.001)\end{array}$ & $\begin{array}{c}-0.011^{* * *} \\
(0.001)\end{array}$ & $\begin{array}{c}-0.008^{* * *} \\
(0.001)\end{array}$ & $\begin{array}{c}-0.009 * * * \\
(0.001)\end{array}$ & $\begin{array}{c}-0.012^{* * *} \\
(0.001)\end{array}$ & $\begin{array}{c}-0.013^{* * *} \\
(0.001)\end{array}$ \\
\hline Negative NI & $\begin{array}{c}0.016^{* * *} \\
(0.004)\end{array}$ & $\begin{array}{c}0.012^{* * *} \\
(0.004)\end{array}$ & $\begin{array}{l}-0.003 \\
(0.003)\end{array}$ & $\begin{array}{c}0.009 \\
(0.009)\end{array}$ & $\begin{array}{c}0.029 * * * \\
(0.005)\end{array}$ & $\begin{array}{c}0.025^{* * *} \\
(0.004)\end{array}$ \\
\hline R\&D Missing Dummy & $\begin{array}{c}-0.032^{* * *} \\
(0.004)\end{array}$ & $\begin{array}{c}-0.027^{* * *} \\
(0.004)\end{array}$ & $\begin{array}{c}-0.017^{* * *} \\
(0.005)\end{array}$ & $\begin{array}{c}-0.030^{* * *} \\
(0.008)\end{array}$ & $\begin{array}{c}-0.053^{* * *} \\
(0.004)\end{array}$ & $\begin{array}{c}-0.049^{* * *} \\
(0.004)\end{array}$ \\
\hline Foreign Sales & & & $\begin{array}{c}0.000 \\
(0.000)\end{array}$ & & & \\
\hline Net Debt Issues & & & $\begin{array}{c}0.159^{* * *} \\
(0.019)\end{array}$ & & & \\
\hline Net Equity Issues & & & $\begin{array}{c}0.130 * * * \\
(0.025)\end{array}$ & & & \\
\hline Intercept & $\begin{array}{c}0.307^{* * *} \\
(0.007)\end{array}$ & $\begin{array}{c}0.262^{* * *} \\
(0.020)\end{array}$ & $\begin{array}{c}0.243^{* * *} \\
(0.012)\end{array}$ & $\begin{array}{c}0.308^{* * *} \\
(0.009)\end{array}$ & $\begin{array}{c}0.389^{* * *} \\
(0.015)\end{array}$ & $\begin{array}{c}0.335^{* * *} \\
(0.039)\end{array}$ \\
\hline Year dummies? & No & Yes & Yes & No & No & Yes \\
\hline Industry dummies? & No & Yes & Yes & No & No & Yes \\
\hline Observations & 117,410 & 117,410 & 23,925 & 117,410 & 36,971 & 36,971 \\
\hline Adj. R-squared & 0.357 & 0.382 & 0.437 & 0.359 & 0.369 & 0.402 \\
\hline
\end{tabular}


Table 5

\section{Panel Regressions of Leverage on Corruption}

The dependent variable is leverage. The sample includes all Compustat firm-years 1980-2009 that include: headquarter location data, positive book value of assets and sales, and accounting data. Financial firms (SIC 6000-6999) and utilities (SIC 4900-4999) are excluded from the main sample, which leaves an unbalanced panel of 117,410 firm-years in 14,044 unique firms. Models (5) and (6) use the state corruption ranking from the State Integrity Investigation. Industry dummies are for two digit SIC codes. Standard errors are below each coefficient estimate in parentheses. All models use heteroscedasticity robust standard errors clustered by firm and time (Roger's standard errors), except the Fama-MacBeth model which uses Newey-West standard errors to mitigate the effect of autocorrelation in the error term. ${ }^{* * *},{ }^{* *}$, and ${ }^{*}$ denote significance at the $.01, .05$, and .1 levels, respectively. Variable definitions are provided in the Appendix.

\begin{tabular}{|c|c|c|c|c|c|}
\hline Model & $\begin{array}{c}(1) \\
\text { Pooled } \\
\text { OLS }\end{array}$ & $\begin{array}{c}(2) \\
\text { Pooled } \\
\text { OLS }\end{array}$ & $\begin{array}{c}(3) \\
\text { Fama- } \\
\text { MacBeth }\end{array}$ & $\begin{array}{c}(4) \\
\text { Pooled } \\
\text { OLS }\end{array}$ & $\begin{array}{c}(5) \\
\text { Pooled } \\
\text { OLS }\end{array}$ \\
\hline Convictions per 100,000 & $\begin{array}{c}0.029^{* * *} \\
(0.006)\end{array}$ & $\begin{array}{c}0.021^{* * *} \\
(0.005)\end{array}$ & $\begin{array}{c}0.033^{* * *} \\
(0.008)\end{array}$ & & \\
\hline Survey Corruption & & & & $\begin{array}{c}0.002^{* * *} \\
(0.000)\end{array}$ & $\begin{array}{c}0.002^{* * * *} \\
(0.000)\end{array}$ \\
\hline Market-to-book & $\begin{array}{l}0.005^{*} \\
(0.003)\end{array}$ & $\begin{array}{c}0.006^{* *} \\
(0.003)\end{array}$ & $\begin{array}{l}-0.001 \\
(0.006)\end{array}$ & $\begin{array}{c}0.017^{* * *} \\
(0.003)\end{array}$ & $\begin{array}{c}0.018^{* * * *} \\
(0.003)\end{array}$ \\
\hline PP\&E & $\begin{array}{c}0.277^{* * *} \\
(0.015)\end{array}$ & $\begin{array}{c}0.265^{* * *} \\
(0.015)\end{array}$ & $\begin{array}{c}0.235^{* * *} \\
(0.030)\end{array}$ & $\begin{array}{c}0.314^{* * *} \\
(0.020)\end{array}$ & $\begin{array}{c}0.301^{* * * *} \\
(0.026)\end{array}$ \\
\hline Ln(Sales) & $\begin{array}{c}0.014^{* * *} \\
(0.001)\end{array}$ & $\begin{array}{c}0.011^{* * *} \\
(0.001)\end{array}$ & $\begin{array}{c}0.016^{* * *} \\
(0.001)\end{array}$ & $\begin{array}{c}0.016^{* * *} \\
(0.002)\end{array}$ & $\begin{array}{c}0.011^{* * * *} \\
(0.002)\end{array}$ \\
\hline Altman-Z & $\begin{array}{c}-0.016^{* * *} \\
(0.001)\end{array}$ & $\begin{array}{c}-0.017^{* * *} \\
(0.001)\end{array}$ & $\begin{array}{c}-0.023^{\text {*** }} \\
(0.003)\end{array}$ & $\begin{array}{c}-0.014^{* * *} \\
(0.001)\end{array}$ & $\begin{array}{c}-0.014^{* * *} \\
(0.001)\end{array}$ \\
\hline EBITDA & $\begin{array}{c}-0.036^{* *} \\
(0.017)\end{array}$ & $\begin{array}{l}-0.029^{*} \\
(0.016)\end{array}$ & $\begin{array}{l}-0.002 \\
(0.009)\end{array}$ & $\begin{array}{l}-0.032 \\
(0.023)\end{array}$ & $\begin{array}{l}-0.023 \\
(0.022)\end{array}$ \\
\hline Intercept & $\begin{array}{c}0.121^{* * *} \\
(0.015)\end{array}$ & $\begin{array}{c}0.138^{* * *} \\
(0.039)\end{array}$ & $\begin{array}{c}0.149^{* * *} \\
(0.039)\end{array}$ & $\begin{array}{l}-0.004 \\
(0.017)\end{array}$ & $\begin{array}{c}0.090 \\
(0.064)\end{array}$ \\
\hline Year dummies? & No & Yes & No & No & Yes \\
\hline Industry dummies? & No & Yes & No & No & Yes \\
\hline Observations & 117,410 & 117,410 & 117,410 & 36,971 & 36,971 \\
\hline Adj. R-squared & 0.285 & 0.310 & 0.250 & 0.387 & 0.407 \\
\hline
\end{tabular}


Table 6

\section{Univariate Comparison of Performance by Corruption}

The sample includes all Compustat firm-years from 1980-2009 that include: headquarter location data, positive book value of assets and sales, and cash flow data. Financial firms (SIC 6000-6999) and utilities (SIC 4900-4999) are excluded from the sample. The unit of observation is the firm, where the value is the firm's time series median. These data are then split in the into corrupt and non-corrupt based on the highest and lowest quartiles of per capita corruption, respectively. Finally, firms are matched on size and industry for comparison. Means [medians] are reported for each group as well as a t-test for difference in means [z-value from a rank-sum test]. ***, **, and * denote significance at the .01, .05, and .1 levels, respectively. Panel A contains results from the full sample of firms. In Panels B-E, only financially constrained firms are examined. Please see in-text definitions of financial constraint criteria. Variable definitions are in the Appendix.

\begin{tabular}{|c|c|c|c|c|c|c|}
\hline & \multicolumn{2}{|c|}{ Non-corrupt } & \multicolumn{2}{|c|}{ Corrupt } & \multirow{2}{*}{\multicolumn{2}{|c|}{$\begin{array}{c}\text { T-value difference in Means } \\
\text { [Rank-sum test }]\end{array}$}} \\
\hline & \multicolumn{2}{|c|}{ Mean [Median] } & \multicolumn{2}{|c|}{ Mean [Median] } & & \\
\hline \multicolumn{7}{|c|}{ Panel A: Full Sample } \\
\hline $\mathrm{ROA}$ & -0.204 & {$[0.004]$} & -0.268 & {$[0.003]$} & 1.159 & {$[-0.091]$} \\
\hline ROE & 0.030 & {$[0.040]$} & -0.235 & {$[0.051]$} & 1.576 & {$[-3.070] * * *$} \\
\hline $\mathrm{OCF}$ & -0.076 & {$[0.073]$} & -0.136 & {$[0.076]$} & 1.427 & {$[-0.191]$} \\
\hline OCF (SoCF) & -0.099 & {$[0.039]$} & -0.202 & {$[0.037]$} & $1.705 *$ & {$[1.763]^{*}$} \\
\hline NI & -0.206 & {$[0.006]$} & -0.270 & {$[0.002]$} & 1.140 & {$[0.193]$} \\
\hline EBI & -0.092 & {$[0.064]$} & -0.152 & {$[0.067]$} & 1.433 & {$[-0.159]$} \\
\hline \multicolumn{7}{|c|}{ Panel B: Size Constrained } \\
\hline ROA & -0.414 & {$[-0.114]$} & -0.563 & {$[-0.129]$} & 1.267 & {$[1.020]$} \\
\hline ROE & 0.035 & {$[-0.034]$} & -0.528 & {$[-0.019]$} & 1.581 & {$[-1.235]$} \\
\hline OCF & -0.256 & {$[-0.043]$} & -0.400 & {$[-0.052]$} & 1.636 & {$[1.636]$} \\
\hline OCF (SoCF) & -0.264 & {$[-0.040]$} & -0.447 & {$[-0.062]$} & 1.569 & {$[2.826] * * *$} \\
\hline NI & -0.418 & {$[-0.114]$} & -0.566 & {$[-0.124]$} & 1.254 & {$[1.016]$} \\
\hline EBI & -0.264 & {$[-0.036]$} & -0.407 & {$[-0.046]$} & 1.617 & {$[1.554]$} \\
\hline
\end{tabular}


Table 6--Continued

\begin{tabular}{|c|c|c|c|c|c|c|}
\hline & \multicolumn{2}{|c|}{ Non-corrupt } & \multicolumn{2}{|c|}{ Corrupt } & \multirow{2}{*}{\multicolumn{2}{|c|}{$\begin{array}{c}\text { T-value difference in Means } \\
\text { [Rank-sum test }]\end{array}$}} \\
\hline & \multicolumn{2}{|c|}{ Mean [Median] } & \multicolumn{2}{|c|}{ Mean [Median] } & & \\
\hline \multicolumn{7}{|c|}{ Panel C: Payout Constrained } \\
\hline $\mathrm{ROA}$ & -0.284 & {$[-0.047]$} & -0.380 & {$[-0.046]$} & 1.301 & {$[0.852]$} \\
\hline $\mathrm{ROE}$ & 0.010 & {$[0.004]$} & -0.349 & {$[0.012]$} & 1.617 & {$[-2.172] * *$} \\
\hline OCF & -0.147 & {$[0.023]$} & -0.236 & {$[0.022]$} & 1.608 & {$[0.457]$} \\
\hline $\mathrm{OCF}(\mathrm{SoCF})$ & -0.149 & {$[-0.002]$} & -0.282 & {$[0.004]$} & $1.772 *$ & {$[2.097] * *$} \\
\hline NI & -0.287 & {$[-0.043]$} & -0.381 & {$[-0.046]$} & 1.276 & {$[1.038]$} \\
\hline EBI & -0.156 & {$[0.023]$} & -0.244 & {$[0.025]$} & 1.594 & {$[0.356]$} \\
\hline \multicolumn{7}{|c|}{ Panel D: Bond Constrained } \\
\hline $\mathrm{ROA}$ & -0.252 & {$[-0.024]$} & -0.391 & {$[-0.023]$} & 1.544 & {$[0.399]$} \\
\hline $\mathrm{ROE}$ & 0.104 & {$[0.022]$} & -0.334 & {$[0.032]$} & $1.669 *$ & {$[-1.343]$} \\
\hline OCF & -0.114 & {$[0.051]$} & -0.239 & {$[0.048]$} & $1.853^{*}$ & {$[0.625]$} \\
\hline $\mathrm{OCF}(\mathrm{SoCF})$ & -0.131 & {$[0.019]$} & -0.279 & {$[0.018]$} & $1.662 *$ & {$[1.208]$} \\
\hline NI & -0.253 & {$[-0.022]$} & -0.393 & {$[-0.025]$} & 1.547 & {$[0.464]$} \\
\hline EBI & -0.125 & {$[0.050]$} & -0.251 & {$[0.046]$} & $1.848 *$ & {$[0.595]$} \\
\hline \multicolumn{7}{|c|}{ Panel E: Short-term Paper Constrained } \\
\hline ROA & -0.206 & {$[-0.004]$} & -0.312 & {$[-0.003]$} & 1.458 & {$[-0.276]$} \\
\hline $\mathrm{ROE}$ & 0.087 & {$[0.036]$} & -0.255 & {$[0.046]$} & 1.613 & {$[-2.355] * *$} \\
\hline $\mathrm{OCF}$ & -0.074 & {$[0.072]$} & -0.170 & {$[0.071]$} & $1.753 *$ & {$[0.380]$} \\
\hline $\mathrm{OCF}(\mathrm{SoCF})$ & -0.094 & {$[0.037]$} & -0.216 & {$[0.035]$} & $1.694^{*}$ & {$[1.421]$} \\
\hline NI & -0.207 & {$[0.000]$} & -0.314 & {$[-0.005]$} & 1.461 & [-0.099] \\
\hline EBI & -0.087 & {$[0.065]$} & -0.183 & {$[0.064]$} & $1.747 *$ & {$[0.437]$} \\
\hline
\end{tabular}


Table 7

\section{Panel Regressions of Market-to-book on Corruption}

The sample includes all Compustat firm-years from 1980-2009 that include: headquarter location data, positive book value of assets and sales, and accounting data. Financial firms (SIC 6000-6999) and utilities (SIC 4900-4999) are excluded from the sample. The dependent variable is the ratio of the market value of assets to the book value of assets. The middle regressions include only firm-year observations that are classified as "constrained" according to various criteria. Please see the in-text definitions for constraint criteria. Standard errors are in parentheses below each coefficient estimate. Standard errors are heteroscedasticity robust Rogers standard errors clustered by firm. ***, **, and * denote significance at the .01, .05, and .1 levels, respectively. Variable definitions are provided in the Appendix. 
Financial constraint criteria

\begin{tabular}{|c|c|c|c|c|c|}
\hline & & Size & Payout & Bond ratings & Paper \\
\hline \multirow[t]{2}{*}{ Convictions per 100,000} & $-0.112^{* * *}$ & $-0.111^{* * *}$ & $-0.087^{* *}$ & $-0.132^{* *}$ & -0.079 \\
\hline & $(0.036)$ & $(0.039)$ & $(0.038)$ & $(0.052)$ & $(0.089)$ \\
\hline \multirow[t]{2}{*}{ Constrained Indicator } & & $-0.827^{* * *}$ & -0.044 & $-0.489^{* * *}$ & $-0.706^{* * *}$ \\
\hline & & $(0.143)$ & $(0.039)$ & $(0.045)$ & $(0.056)$ \\
\hline Convictions $\mathrm{x}$ & & 0.044 & -0.044 & 0.016 & -0.042 \\
\hline Constrained & & $(0.115)$ & $(0.062)$ & $(0.064)$ & $(0.090)$ \\
\hline \multirow[t]{2}{*}{ Real Size } & $-0.116^{* * *}$ & $-0.275^{* * *}$ & $-0.125^{* * *}$ & $-0.160^{* * *}$ & $-0.142^{* * *}$ \\
\hline & $(0.011)$ & $(0.032)$ & $(0.013)$ & $(0.014)$ & $(0.013)$ \\
\hline \multirow[t]{2}{*}{ EBITDA } & $3.281 * * *$ & $2.181^{* * *}$ & $2.975^{* * *}$ & $3.099^{* * *}$ & $2.965^{* * *}$ \\
\hline & $(0.460)$ & $(0.555)$ & $(0.476)$ & $(0.471)$ & $(0.464)$ \\
\hline \multirow[t]{2}{*}{ Intangibles } & $0.631^{* * *}$ & $0.578^{* * *}$ & $0.689^{* * *}$ & $0.707^{* * *}$ & $0.649^{* * *}$ \\
\hline & $(0.063)$ & $(0.089)$ & $(0.070)$ & $(0.066)$ & $(0.065)$ \\
\hline \multirow[t]{2}{*}{ Leverage } & -0.149 & $0.338^{* *}$ & -0.040 & -0.012 & 0.217 \\
\hline & $(0.125)$ & $(0.167)$ & $(0.135)$ & $(0.131)$ & $(0.134)$ \\
\hline \multirow[t]{2}{*}{$\mathrm{R} \& \mathrm{D}$} & $0.285^{* * *}$ & $0.422^{* * *}$ & $0.278^{* * *}$ & $0.267^{* * *}$ & $0.261^{* * *}$ \\
\hline & $(0.039)$ & $(0.061)$ & $(0.039)$ & $(0.040)$ & $(0.040)$ \\
\hline \multirow[t]{2}{*}{ Cash Flow } & $-6.226^{* * *}$ & $-5.278 * * *$ & $-5.959^{* * *}$ & $-5.987 * * *$ & $-5.802 * * *$ \\
\hline & $(0.474)$ & $(0.542)$ & $(0.482)$ & $(0.483)$ & $(0.477)$ \\
\hline \multirow[t]{2}{*}{ Age } & -0.028 & $0.109^{* * *}$ & -0.020 & -0.030 & $-0.052^{* *}$ \\
\hline & $(0.021)$ & $(0.029)$ & $(0.022)$ & $(0.022)$ & $(0.022)$ \\
\hline \multirow[t]{2}{*}{ DE Incorporation } & $0.133^{* * *}$ & $0.130^{* * *}$ & $0.145^{* * *}$ & $0.116^{* * *}$ & $0.146^{* * *}$ \\
\hline & $(0.033)$ & $(0.049)$ & $(0.036)$ & $(0.036)$ & $(0.035)$ \\
\hline \multirow[t]{2}{*}{ Intercept } & $1.999 * * *$ & $2.707^{* * *}$ & $2.112^{* * *}$ & $2.079^{* * *}$ & $2.332^{* * *}$ \\
\hline & $(0.147)$ & $(0.285)$ & $(0.172)$ & $(0.155)$ & $(0.150)$ \\
\hline Year dummies? & Yes & Yes & Yes & Yes & Yes \\
\hline Industry dummies? & No & No & No & No & No \\
\hline Observations & 94,711 & 54,085 & 83,931 & 83,177 & 83,177 \\
\hline Adj. R-squared & 0.292 & 0.355 & 0.295 & 0.298 & 0.302 \\
\hline
\end{tabular}




\section{Table 8}

\section{Alternative Cash Holdings Models}

The sample includes all Compustat firm-years from 1980-2009 that include: headquarter location data, positive book value of assets and sales, and accounting data. Financial firms (SIC 6000-6999) and utilities (SIC 4900-4999) are excluded from the sample, which leaves an unbalanced panel of 117,410 firm-years for 14,044 unique firms. The first and second models use the one-year and two-year changes, respectively, for all variables for which it is appropriate. The third model contains dummies for every firm, or firm fixed effects. The fourth, fifth, and sixth models contain additional independent variables. The seventh model is the second stage of a 2SLS regression and contains the instrumented value of state corruption per 100,000. The regressions include previous controls, but they are not reported. Standard errors are in parentheses below each coefficient estimate. Standard errors are all heteroscedasticity robust Rogers standard errors clustered by firm and time. ***, **, and * denote significance at the .01, .05, and .1 levels, respectively. The weak IV test is a Kleigbergen and Paap (2006) Wald test of a relation between state corruption and the instrument. Exogeneity test is a Durbin-Wu-Hausman test. Variable definitions are provided in the Appendix. 


\begin{tabular}{|c|c|c|c|c|c|c|c|}
\hline Model & $\begin{array}{c}(1) \\
\text { One-year } \\
\text { Changes }\end{array}$ & $\begin{array}{c}(2) \\
\text { Two-Year } \\
\text { Changes }\end{array}$ & $\begin{array}{c}(3) \\
\text { Firm Fixed } \\
\text { Effects }\end{array}$ & $\begin{array}{c}(4) \\
\text { Additional } \\
\text { Controls }\end{array}$ & $\begin{array}{c}\text { (5) } \\
\text { Additional } \\
\text { Controls }\end{array}$ & $\begin{array}{c}\text { (6) } \\
\text { Additional } \\
\text { Controls }\end{array}$ & $\begin{array}{c}\text { (7) } \\
\text { IV Estimation }\end{array}$ \\
\hline Convictions per 100,000 & $\begin{array}{c}-0.003^{* *} \\
(0.001)\end{array}$ & $\begin{array}{c}-0.006^{* * *} \\
(0.002)\end{array}$ & $\begin{array}{c}-0.007^{* * *} \\
(0.002)\end{array}$ & $\begin{array}{c}-0.016^{* * *} \\
(0.003)\end{array}$ & $\begin{array}{c}-0.018^{* * *} \\
(0.006)\end{array}$ & $\begin{array}{c}-0.028^{* * *} \\
(0.006)\end{array}$ & $\begin{array}{l}-0.009 \\
-0.021\end{array}$ \\
\hline Industry Unionization Rate & & & & $\begin{array}{c}-0.001^{* * *} \\
(0.000)\end{array}$ & & & \\
\hline Inventory & & & & $\begin{array}{c}-0.393^{* * *} \\
(0.013)\end{array}$ & & & \\
\hline Product Market Fluidity & & & & & $\begin{array}{c}0.015^{* * *} \\
(0.001)\end{array}$ & & \\
\hline Per Capita Income & & & & & & $\begin{array}{c}0.000^{* * *} \\
(0.000)\end{array}$ & \\
\hline Educational Attainment & & & & & & $\begin{array}{c}0.002^{* * *} \\
(0.000)\end{array}$ & \\
\hline Unemployment & & & & & & $\begin{array}{c}0.001 \\
(0.001)\end{array}$ & \\
\hline & & & & & Additi & control var & es not reported \\
\hline Intercept & $\begin{array}{c}-0.009^{* * *} \\
(0.000)\end{array}$ & $\begin{array}{c}-0.011^{* * *} \\
(0.000)\end{array}$ & $\begin{array}{c}0.260^{* * *} \\
(0.007)\end{array}$ & $\begin{array}{c}0.402^{* * *} \\
(0.008)\end{array}$ & $\begin{array}{c}0.260^{* * *} \\
(0.013)\end{array}$ & $\begin{array}{c}0.185^{* * *} \\
(0.020)\end{array}$ & $\begin{array}{c}0.309^{* * *} \\
(0.008)\end{array}$ \\
\hline $\begin{array}{l}\text { Weak IV Test } \\
\text { Exogeneity Test }\end{array}$ & & & & & & & $\begin{array}{c}3117.72^{* * *} \\
0.603\end{array}$ \\
\hline Observations & 103,366 & 90,690 & 117,410 & 90,323 & 39,582 & 44,645 & 105,701 \\
\hline Adj. R-squared & 0.093 & 0.086 & 0.686 & 0.431 & 0.512 & 0.379 & 0.359 \\
\hline
\end{tabular}


Table 9

\section{Alternative Leverage Models}

The sample includes all Compustat firm-years from 1980-2009 that include: headquarter location data, positive book value of assets and sales, and accounting data. Financial firms (SIC 6000-6999) and utilities (SIC 4900-4999) are excluded from the sample, which leaves an unbalanced panel of 117,410 firm-years for 14,044 unique firms. The first and second models use the one-year and two-year changes, respectively, in the variables (including cash holdings). The third model contains dummies for every firm, or firm fixed effects. The fourth and fifth models contain additional independent variables. The sixth model is the second stage of a 2SLS regression and contains the instrumented value of state corruption per 100,000. The dependent variable is leverage. The regressions include previous controls, but they are not reported. Standard errors are in parentheses below each coefficient estimate. Standard errors are all heteroscedasticity robust Rogers standard errors clustered by firm and time. ${ }^{* * *},{ }^{* *}$, and ${ }^{*}$ denote significance at the $.01, .05$, and .1 levels, respectively. The weak IV test is a Kleigbergen and Paap (2006) Wald test of a relation between state corruption and the instrument. Exogeneity test is a Durbin-Wu-Hausman test. Variable definitions are provided in the Appendix.
$(1)$
$(2)$
(3)
(4)
(5)
(6)

One-year Two-Year Firm Fixed Additional Additional IV

\begin{tabular}{lcccccc} 
Model & Changes & Changes & Effects & Controls & Controls & Estimation \\
\hline Convictions per 100,000 & -0.002 & 0.000 & $0.009^{* *}$ & $0.035^{* * *}$ & $0.036^{* * *}$ & $0.153^{* * *}$ \\
& $(0.003)$ & $(0.003)$ & $(0.004)$ & $(0.006)$ & $(0.009)$ & $(0.036)$ \\
Industry Unionization Rate & & & & $0.001^{* * *}$ & &
\end{tabular}

Per Capita Income

Educational Attainment $-0.004^{* * *}$

Unemployment $-0.004^{* *}$

Additional control variables not reported

$\begin{array}{lcccccc}\text { Intercept } & 0.008^{* * *} & 0.009^{* * *} & 0.091^{* * *} & 0.104^{* * *} & 0.218^{* * *} & 0.078^{* * *} \\ & (0.001) & (0.001) & (0.011) & (0.016) & (0.024) & (0.012) \\ & & & & & & 3153.74^{* * *} \\ \text { Weak IV Test } & & & & & & 8.681^{* * *} \\ \text { Exogeneity Test } & 103,366 & 90,690 & 117,410 & 90,827 & 44,645 & 105,701 \\ \text { Observations } & 0.195 & 0.219 & 0.626 & 0.285 & 0.365 & 0.289 \\ \text { Adj. R-squared } & & & & & & \end{array}$


Table 10

\section{Subsample Regressions of Cash Holdings and Leverage}

The sample includes all Compustat firm-years from 1980-2009 that include: headquarter location data, positive book value of assets and sales, and accounting data. Financial firms (SIC 6000-6999) and utilities (SIC 4900-4999) are excluded from the sample, which leaves an unbalanced panel of 117,410 firm-years for 14,044 unique firms. Corrupt indicator takes a value of $1(0)$ if the district is in the top (bottom) quartile of convictions in year t. Each column contains a different indicator or continuous variable and its interaction with the corrupt indicator, labeled below the legend. In Panel A (B), the dependent variable is the cash ratio (leverage). The regressions include all the controls from previous tables, but they are not reported. Standard errors are in parentheses below each coefficient estimate. Standard errors are all heteroscedasticity robust Rogers standard errors clustered by firm and time. ***,**, and ${ }^{*}$ denote significance at the .01, .05 , and .1 levels, respectively. Variable definitions are provided in the Appendix.

\begin{tabular}{|c|c|c|c|c|c|}
\hline & \multicolumn{3}{|c|}{ Financials \& } & $\begin{array}{c}\text { Count State } \\
\text { Operations } \\
\end{array}$ & $\begin{array}{c}\text { Concentration } \\
\text { Around HQ }\end{array}$ \\
\hline \multicolumn{6}{|c|}{ Panel A: Dependent Variable is Cash/Assets } \\
\hline Corrupt Indicator & $\begin{array}{c}-0.021^{* * *} \\
(0.005)\end{array}$ & $\begin{array}{c}-0.021^{* * *} \\
(0.005)\end{array}$ & $\begin{array}{l}-0.010 \\
(0.007)\end{array}$ & $\begin{array}{c}-0.035^{* * *} \\
(0.009)\end{array}$ & $\begin{array}{l}-0.001 \\
(0.006)\end{array}$ \\
\hline Firm Characteristic & & $\begin{array}{c}0.031^{* * *} \\
(0.009)\end{array}$ & $\begin{array}{c}-0.004^{* * *} \\
(0.001)\end{array}$ & $\begin{array}{c}-0.003^{* * *} \\
(0.000)\end{array}$ & $\begin{array}{c}0.090^{* * * *} \\
(0.014)\end{array}$ \\
\hline $\begin{array}{l}\text { Indicator x Firm } \\
\text { Characteristic }\end{array}$ & & $\begin{array}{l}0.022^{*} \\
(0.014)\end{array}$ & $\begin{array}{c}-0.002^{* *} \\
(0.001)\end{array}$ & $\begin{array}{l}0.001^{* *} \\
(0.000)\end{array}$ & $\begin{array}{c}-0.060 * * * \\
(0.016)\end{array}$ \\
\hline Intercept & $\begin{array}{c}0.305^{* * *} \\
(0.008)\end{array}$ & $\begin{array}{c}0.312^{* * *} \\
(0.008)\end{array}$ & $\begin{array}{l}0.299 * * * \\
(0.008)\end{array}$ & $\begin{array}{c}\text { Control variabl } \\
0.320^{* * *} \\
(0.013)\end{array}$ & $\begin{array}{c}\text { sot reported } \\
0.262^{* * *} \\
(0.012)\end{array}$ \\
\hline Observations & 52,683 & 56,484 & 52,683 & 21,399 & 21,399 \\
\hline Adj. R-squared & 0.359 & 0.357 & 0.359 & 0.430 & 0.432 \\
\hline \multicolumn{6}{|c|}{ Panel B: Dependent Variable is Leverage } \\
\hline Corruption Indicator & $\begin{array}{c}0.030^{* * *} \\
(0.007)\end{array}$ & $\begin{array}{c}0.030^{* * *} \\
(0.007)\end{array}$ & $\begin{array}{l}0.032^{* *} \\
(0.014)\end{array}$ & $\begin{array}{c}0.063^{* * *} \\
(0.013)\end{array}$ & $\begin{array}{l}0.021^{*} \\
(0.011)\end{array}$ \\
\hline Firm Characteristic & & $\begin{array}{l}0.022^{* *} \\
(0.010)\end{array}$ & $\begin{array}{c}0.015^{* * *} \\
(0.002)\end{array}$ & $\begin{array}{c}0.003^{* * *} \\
(0.001)\end{array}$ & $\begin{array}{c}-0.092^{* * *} \\
(0.020)\end{array}$ \\
\hline $\begin{array}{l}\text { Indicator x Firm } \\
\text { Characteristic }\end{array}$ & & $\begin{array}{c}-0.057^{* * *} \\
(0.014)\end{array}$ & $\begin{array}{l}-0.000 \\
(0.002)\end{array}$ & $\begin{array}{c}-0.002^{* * *} \\
(0.001)\end{array}$ & $\begin{array}{l}0.049^{*} \\
(0.026)\end{array}$ \\
\hline Intercept & $\begin{array}{c}0.114^{* * *} \\
(0.018)\end{array}$ & $\begin{array}{c}0.118^{* * *} \\
(0.017)\end{array}$ & $\begin{array}{c}0.113^{* * *} \\
(0.019)\end{array}$ & $\begin{array}{c}\text { Control variable } \\
0.039^{* *} \\
(0.020)\end{array}$ & $\begin{array}{c}\text { not reported } \\
0.102^{* * *} \\
(0.019)\end{array}$ \\
\hline Observations & 52,683 & 56,484 & 52,683 & 21,399 & 21,399 \\
\hline Adj. R-squared & 0.278 & 0.276 & 0.278 & 0.246 & 0.248 \\
\hline
\end{tabular}

